\title{
Comparative foraging ecology of planktivorous auklets in relation to ocean physics and prey availability
}

\author{
George L. Hunt $\mathrm{Jr}^{1, *}$, Robert W. Russell ${ }^{1, * *}$, Kenneth O. Coyle ${ }^{2}$, Thomas Weingartner ${ }^{2}$ \\ ${ }^{1}$ Department of Ecology and Evolutionary Biology, University of California, Irvine, California 92697, USA \\ ${ }^{2}$ Institute of Marine Sciences, University of Alaska, Fairbanks, Alaska 99775, USA
}

\begin{abstract}
We tested the hypothesis that the spatial distributions of foraging least, crested and parakeet auklets (Aethia pusilla, A. cristatella and A. psittacula, respectively) in the shallow passes of the Aleutian Islands would be determined by physical mechanisms that control near-surface prey concentrations. We recorded currents using an Acoustic Doppler Current Profiler, volume scattering using 200 and $420 \mathrm{kHz}$ scientific echosounders, and the numbers of foraging birds. Zooplankton were sampled using a multiple opening/closing net and environmental sampling system (MOCNESS). Prey choice of birds was ascertained by collecting foraging birds and examining their stomach contents. Most sampling occurred between 8 July and 6 August 1993, when we conducted 50 passages along a transect that crossed a sill between Unalga and Kavalga Islands, western Aleutian Islands, thereby sampling the toraging activity of auklets at a variety of times of day and tidal phases. We found that the abundance of foraging individuals of each of the 3 auklet species was a function of tidal speed. Auklet species were selective about the species of prey taken. Regardless of tidal direction, crested auklets foraged on euphausiids upwelled on the upstream side of the pass, whereas least auklets consumed copepods concentrated in near-surface convergences on the downstream side. Parakeet auklets foraged over the top of the pass and took fish and invertebrates. Tidal speed and direction influenced the distance between the peak numbers of some, but not all, species of auklets. Auklet prey preferences dictated where they foraged in the pass and the physical mechanisms exploited for successful foraging. Thus, in this instance, resource partitioning by these closely related planktivores was enhanced by a spatial segregation forced by the physical processes that enhanced the availability of prey. Our findings emphasize the important role of physical processes in the structuring of marine communities.
\end{abstract}

KEY WORDS: Biological-physical coupling - Tidal fronts - Least auklet - Crested auklet - Parakeet auklet Aethia pusilla Aethia cristatella . Aethia psittacula Seabird foraging ecology

\section{INTRODUCTION}

In the Northern Hemisphere, continental shelf regions support the majority of resident marine birds. Two features of continental shelves contribute to their importance as foraging areas: shelf waters are highly productive, and continental shelves are characterized

\footnotetext{
-E-mail: glhunt@uci.edu

- Present address: Museum of Natural Science, Louisiana

State University, Baton Rouge, Louisiana 70803-3126, USA
}

by the interaction of currents with bathymetry which can produce spatially and temporally predictable concentrations of prey. Here, we report on the foraging ecology of least (Aethia pusilla), crested (A. cristatella) and parakeet auklets (A. psittacula) and the physical mechanisms that influenced the availability of their zooplankton prey in an Aleutian Islands pass.

Mechanisms responsible for the formation, persistence or dispersal of zooplankton patches are not well understood. In the open ocean, variability in zooplankton aggregation is primarily a function of biological interactions such as grazing and predation, or behavior 
dependent on zooplankton. mobility, such as social interactions, mating aggregations or vertical migrations (Haury \& Wiebe 1982). In stratified water, vertical patchiness is associated with the tendency for zooplankton to accumulate in layers on pycnoclines (Barroclough et al. 1969, Cooney 1989, Fragopoulu \& Lykakis 1990, and references therein).

In coastal systems, the formation of zooplankton patches occurs at the scale of fronts, tidal processes and river plumes and is dominated by physical processes (Pingree et al. 1974, Herman et al. 1981, Gagnon \& Lacroix 1982, Franks 1997). Tidal currents flowing through passes can upwell zooplankton (Thompson \& Golding 1981, Thompson \& Wolanski 1984) and can subsequently concentrate them in vortices and secondary circulation cells (Wolanski \& Hamner 1988, Wolanski et al. 1988). Species of vertically migrating zooplankton may become concentrated when they swim against currents (e.g. Simard et al. 1986, Coyle et al. 1992), or they may be advected into shallow regions and become trapped against the bottom (Genin et al. 1988). Thus, in coastal regions, zooplankton patchiness is likely to be the result of interacting biological and physical factors (Haury et al. 1978, Haury \& Pieper 1987), and the strength of the physical process is likely to determine the extent to which it forces zooplankton patchiness.

Physical features at which foraging seabirds concentrate include oceanic frontal systems (e.g. Kinder et al. 1983, Haney \& McGillivary 1985a, b, Vermeer et al. 1985, Briggs et al. 1988, Hunt \& Harrison 1990 , Decker \& Hunt 1996, Hunt et al. 1996) and tidally driven upwellings and convergences (e.g. Vermeer et al. 1987, Brown \& Gaskin 1988, Cairns \& Schneider 1990). When currents are strong, plankton can be advected to the surface and become available to surface-foraging seabirds (Vermeer et al. 1987, Brown \& Gaskin 1988) When currents are not sufficiently strong to transport zooplankton to the surface, seabird species capable of diving to depth can make use of prey concentrated in subsurface patches (Coyle et al. 1992).

In this study, we investigated the physical processes that determined the horizontal and vertical distribution of zooplankton eaten by least, crested and parakeet auklets that foraged in a shallow tidal pass in the Delarof Islands, western Aleutian Islands. At the outset of our study, we hypothesized that auklets would forage in tidal passes where zooplankton concentrations were predictably available. We expected that, where tidal currents impinged upon the bottom, there would be a consistent spatial organization of the foraging birds based on the depth from which their prey were being transported. Our prediction was that nearsurface layers of zooplankton would surface upstream of deeper layers, and that birds foraging on near- surface layers would form foraging aggregations upstream of birds dependent on deeper layers of prey. We tested these predictions by determining the distributions of the 3 species of foraging auklets, their diets, the horizontal and vertical distribution and abundance of their prey, and the physical processes responsible for determining zooplankton distributions in an Aleutian Islands pass.

\section{STUDY AREA AND FOCAL SPECIES}

The Aleutian Islands form a $2000 \mathrm{~km}$ arc from the Alaska Peninsula in the east to Attu Island in the west (Fig. 1). The shallow passes associated with this chain of islands permit partial communication of waters between the North Pacific Ocean and the Bering Sea. The Delarof Islands, located at $51^{\circ} 35^{\prime} \mathrm{N}, 178^{\circ} 55^{\prime} \mathrm{W}$, form the eastern flank of Amchitka Pass, one of 4 major ocean connections between the North Pacific and the Bering Sea. The bathymetry surrounding the Delarof Islands is complex (Fig. 1). The pass between Unalga and Kavalga islands is $12 \mathrm{~km}$ wide and $54 \mathrm{~m}$ deep. To both the north and south, the sill between the islands slopes away steeply to over $1000 \mathrm{~m}$ depth.

Five species of small planktivorous auklets breed in the Aleutian Islands, of which least, crested and parakeet auklets are relatively abundant in the study area (Sowls et al. 1978). In the vicinity of the Delarof Islands, the principal colonies of auklets are on Gareloi Island, where $400 \times 10^{5}$ least, $186 \times 10^{5}$ crested and $43 \times 10^{5}$ parakeet auklets have been estimated to breed (Sowls et al. 1978). Based on discussions with staff of the Alaska Maritime National Wildlife Refuge and our own observations, these estimates are probably low by a factor of 2 or 3 . The presence of large numbers of auklets foraging near their colonies is important to a study such as this because it facilitates the obtaining of a strong signal-to-noise ratio (high numbers of foraging birds relative to low background numbers) when seeking pattern in foraging distributions. During 1993 , when we made our observations, the auklets were feeding their chicks at colonies on Gareloi Island, $20.5 \mathrm{~km}$ north of the sill.

All species of auklets obtain their food underwater by pursuit diving (Ashmole \& Ashmole 1967). A mean maximum dive depth of $28 \mathrm{~m}$ (range 6 to $43 \mathrm{~m}$ ) was obtained for the $190 \mathrm{~g}$ Cassin's auklet Ptychoramphus aleuticus for birds foraging off colonies in the eastern Queen Charlotte Islands of British Columbia, Canada (Burger \& Powell 1990). Estimates of maximum dive depths have been developed for auklets based on a generalized model relating diving capability to body mass (Burger 1991). Least auklets weigh between 70 and $80 \mathrm{~g}$ and can probably dive to a depth of about 

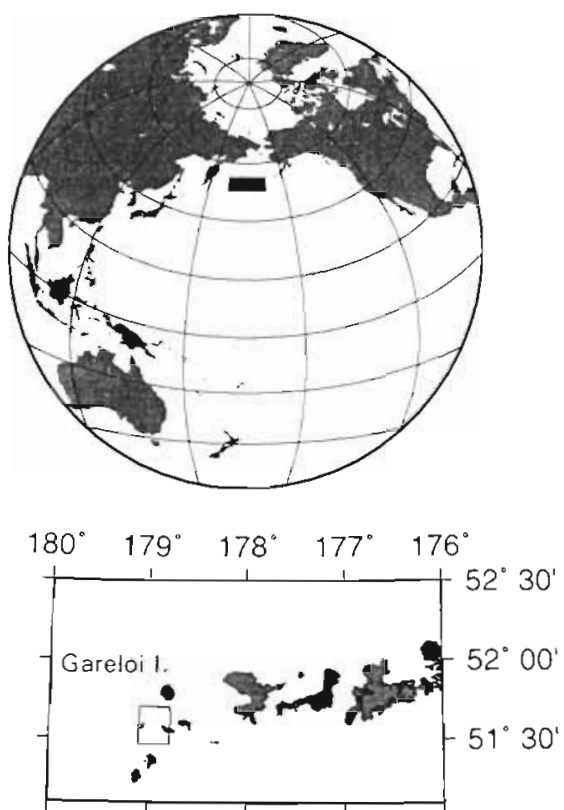

Fig. 1. Locator maps and chart of the bathymetry (in $\mathrm{m}$ ) near the Delarof Islands showing the location of MOCNESS tows in July-August 1993. Tows 9 through 12 and

30 and 31 were taken on the standard transect line

$15 \mathrm{~m}$ (Obst et al. 1995). Based on the model of Burger (1991), crested auklets (about $290 \mathrm{~g}$ ) are estimated to dive to $45 \mathrm{~m}$, whereas the parakeet auklet (about $320 \mathrm{~g}$ ) is estimated to be capable of dives to $49 \mathrm{~m}$.

The summertime food preferences of least, crested and parakeet auklets are well known in the northern and eastern Bering Sea (e.g. Bédard 1969, Hunt et al. 1981, Springer \& Roseneau 1985, Harrison 1987, Piatt et al. 1992), although less is known about their diets in the western Aleutian Islands (Day \& Byrd 1989, Hunt et al. 1993). In general, least auklets specialize on copepods, particularly Neocalanus plumchrus, when available, and crested auklets specialize on euphausiids, particularly Thysanoessa raschii. In contrast, parakeet auklets are more generalized in their diet and take a variety of larval fishes and zooplankton, including gelatinous zooplankton and their commensals (Harrison 1984, 1987).

\section{METHODS}

Description of physical processes. Currents in the study area were measured with a hull-mounted RD Instruments $307 \mathrm{kHz}$ Acoustic Doppler Current Profiler (ADCP) on the RV 'Alpha Helix'. Horizontal velocity data were collected in 2 min ensembles averaged in $4 \mathrm{~m}$ depth bins. The data were written to disk with GPS data from the ship's navigation system to provide time and position for each data record. All contour plots

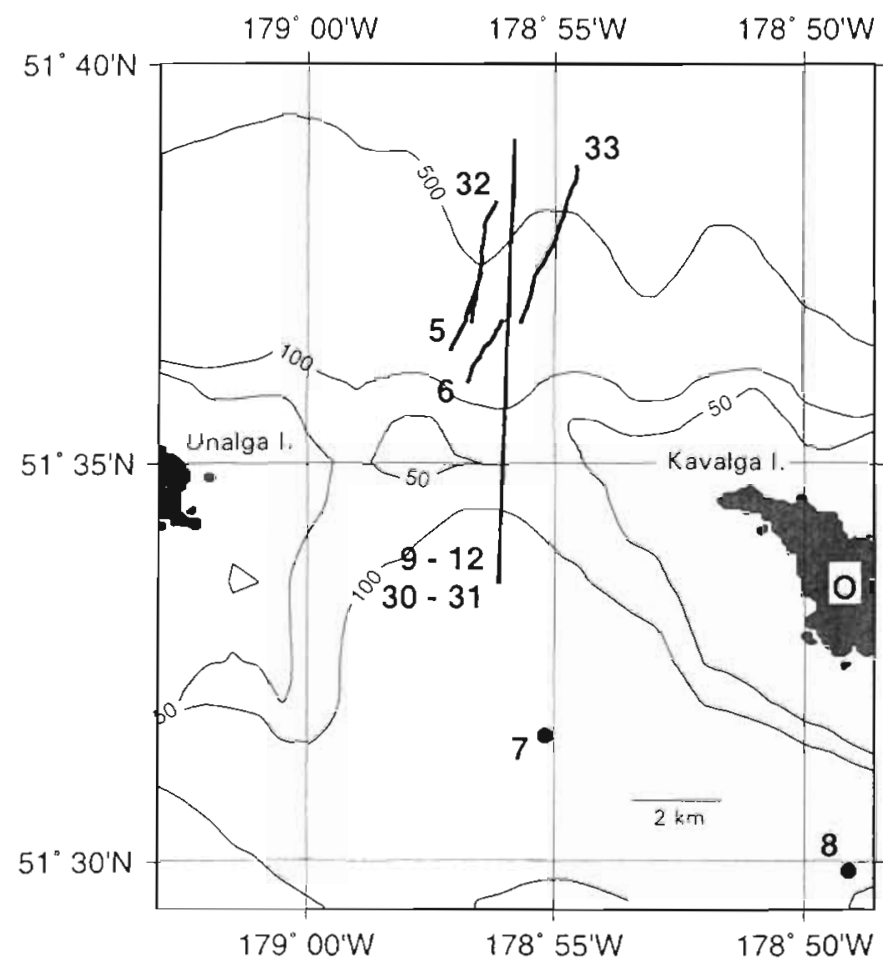

were computer generated using a minimum curvature gridding algorithm. To ascertain the hydrographic structure in the pass, we collected condurtivitytemperature-depth data with a Neil Brown CTD.

In situ fluorescence was measured with a model $Q$ fluorometer mounted on the CTD. The in situ fluorometer was calibrated using water samples collected at discrete depths with Niskin bottles. The samples were extracted in $90 \%$ acetone and fluorescence was measured on a Turner Design bench fluorometer as outlined in Parsons et al. (1984). The bench fluorometer was calibrated using a Hitachi spectrophotometer and chlorophyll extract as outlined in Parsons et al. (1984).

Ornithological studies. Data on the distribution and abundance of foraging auklets were obtained by counting birds observed within a $300 \mathrm{~m}$ radius from directly ahead of the vessel to $90^{\circ}$ off the side with the best visibility. An observer standing in the wheelhouse (eye height about $7.7 \mathrm{~m}$ above the sea's surface) identified birds to species and assessed behaviors such as flying, sitting on the water and foraging. This information was called to a second individual who recorded data, to the nearest tenth of a minute, on a portable computer. Most observations and counts were made with the unaided eye; binoculars were used primarily to check the edge of the transect strip and to confirm identifications. Birds that emerged from the water's surface as the vessel passed were assumed to have been foraging below. Birds on the surface were assumed to be about to forage, or to be resting from a 
previous foraging bout. When numbers of auklets on the water were very high, we omitted observations of flying birds.

Diets of auklets were determined by shooting birds that were sitting on the water or which had just emerged from beneath the surface. We concentrated our collecting in areas where large numbers of birds were foraging. Contents of each alimentary canal, from the mouth to the ventriculus, were removed within an hour of collection and placed in $85 \%$ ethyl alcohol for later identification. Identification of prey was accomplished using a binocular microscope and appropriate taxonomic keys and voucher specimens. Auklets were collected under U.S. Fish and Wildlife Service permit PRT-692454, State of Alaska permits 92-83 and 93-80, and University of California, Irvine, Institutional Animal Research Committee Protocol ARC \#91-1235.

Estimation of volume scattering and zooplankton abundance. Acoustic data were collected at frequencies of 200 and $420 \mathrm{kHz}$ along transects at integration intervals of $1 \mathrm{~min}$ (distance covered $=240 \mathrm{~m}$ ) using a BioSonics model 120 echosounding system and ESP (Echo Signal Processing) integration board. The transducers were deployed in a $v$-fin depressor at $5 \mathrm{~m}$ depth and were towed at $4 \mathrm{~m} \mathrm{~s}^{-1}$ beside the vessel about $3 \mathrm{~m}$ from the hull. The $420 \mathrm{kHz}$ system resolved soundscattering intensity into $1 \mathrm{~m}$ depth intervals from 5 to $55 \mathrm{~m}$ depth. The $200 \mathrm{kHz}$ data were collected in $2 \mathrm{~m}$ depth intervals from 5 to $165 \mathrm{~m}$ depth. Position data were simultaneously collected with a GPS receiver interfaced to the computer. Acoustic data are reported as volume scattering in $\mathrm{dB}$, and were contoured using the minimum curvature gridding algorithm.

Zooplankton were collected with a MOCNESS (multiple opening/closing net and environmental sampling system). Twelve MOCNESS tows were done concurrently with acoustic measurements in the Delarof Pass region (Fig. 1). Each tow consisted of up to 9 nets which were opened and closed at discrete depth intervals relative to specific scattering layers at each site Acoustic data were interfaced with zooplankton data through acoustic data record numbers and net numbers recorded for each tow and by time marks in the data files. Mesh size was $0.505 \mathrm{~mm}$, effective mouth opening was $1 \mathrm{~m}^{2}$, and the system simultaneously recorded salinity, temperature, depth, fluorescence, volume fished and net angle. The samples were preserved in $10 \%$ formalin for later processing. The samples were split to a manageable size with a Folsom splitter, the specimens were sorted and identified to the lowest taxonomic level possible, copepodite stages were determined and wet weights were measured.

Description of transects. In 1992, we completed 4 transects along the $178^{\circ} 57^{\prime} \mathrm{W}$ meridian. In 1993 ,
50 transects were conducted along the $178^{\circ} 56^{\prime} \mathrm{W}$ meridian within latitudinal ranges of either $51^{\circ} 30^{\prime}$ to $51^{\circ} 39^{\prime} \mathrm{N}$ or $51^{\circ} 33^{\prime}$ to $51^{\circ} 41^{\prime} \mathrm{N}$. We also completed 1 transect along the $178^{\circ} 57.5^{\prime} \mathrm{W}$ meridian in 1993. Bird data from 1993 used in this paper were collected on 8 July, 13-15 July, 17-21 July and 5-6 August. For the purpose of standardization, our analyses of bird abundance focus on data obtained between $51^{\circ} 33^{\prime} \mathrm{N}$ $\left(51.55^{\circ} \mathrm{N}\right)$ and $51^{\circ} 37^{\prime} \mathrm{N}\left(51.62^{\circ} \mathrm{N}\right)$ (i.e. along meridianal segments included within both transect types). Hereafter, we use the phrase 'standard transect' to denote north-south transect segments from $51.55^{\circ}$ to $51.62^{\circ} \mathrm{N}$.

On several occasions, transects were terminated prior to reaching the usual endpoint in order to conduct MOCNESS tows. However, when a decision was made to terminate a transect before the usual endpoint but when large numbers of one or more auklet species were still being observed, we attempted to proceed along the line until patches of birds were no longer in evidence. In those instances when we could determine from field observations that the transect had encompassed foraging populations of one or more auklet species, we used data from the shorter transects in our analyses. Thus, there were 43 transects with usable $\mathrm{ADCP}$ data, but not all of them covered the complete length of the 'standard transect'. In one instance, we obtained an incomplete count of least auklets (thus $n=43-1=42)$, and in 3 cases we obtained incomplete counts of crested auklets ( $n=43-3=40$ ). In all 4 of these cases, we excluded use of parakeet auklets because, given their low numbers and patchy distribution, truncation of the transect compromised our ability to quantify their distributions.

Statistical analyses. Spatial distribution of acoustic return: Plots showing the average conditions over the ridge during ebb, flood and slack tides in July 1993 were constructed by pooling the data for each phase of the tide cycle. Duplicate data points were averaged and a minimum curvature grid was generated. The average flood tide condition was based on 9 tide cycles, that for ebb tide on 4 tide cycles and for slack water data were available from 6 periods.

To relate the abundance and biomass of specific taxa of zooplankton to physical features of the water column, we calculated Pearson correlation coefficients between the abundance or biomass of zooplankton and water depth and sigma-t.

Spatial distributions of auklets: Spatial distributions of auklets were analyzed using modal locations of each species along each transect (i.e. latitudes of the bins with highest bird numbers) as replicate data points. A transect was excluded from analyses if its modal bin contained $<20$ individuals for least auklets, $<10$ individuals for crested auklets, or $<5$ individuals for para- 
keet auklets. We chose these thresholds based upon the relative abundance of the 3 species, reasoning that transects not meeting these criteria would not be informative due to a low signal-to-noise ratio. The sample of data used to analyze spatial patterns therefore consisted of all modal locations meeting the criteria described above.

An uncorrectable problem with heteroscedasticity prohibited analysis of this data set using a parametric 2-way analysis of variance (ANOVA). Instead, we compared modal locations of the different species using separate Kruskal-Wallis 1-way ANOVAs for periods of northward and southward current flow. Significant ANOVAs were followed by multiple comparisons among species using pairwise Mann-Whitney $U$-tests. Significance levels for multiple comparisons were corrected using the Bonferroni procedure for familywise Type I error rates of $\leq 0.05$. (A family was considered to be the set of comparisons possible for each current direction.)

We also compared spatial distributions within transects by tabulating the relative ordering of the species with respect to current direction. Here, the null hypothesis was that for each pair of auklet species, the modal location of each species was equally likely to occur upstream or downstream of the other on any given transect. Deviations from null expectations were tested for significance using binomial tests.

Ve used the modai jocation (i.e. the location of the peak density) of each pair within the 3 auklet species as an index of spatial segregation. We assumed that increased current speed would more sharply define the zones of divergence and convergence, and would shift the convergence zones farther downstream from the sill. Therefore, we tested the hypothesis that the degree of segregation between auklet species would increase with increasing current strength by regressing these overlap indices on peak current strength along each transect. Criteria for selecting transects for these analyses were as described above. Sample sizes reflected the number of pairwise comparisons possible.

Relationships between foraging behavior and physical processes: Responses of each auklet species to oceanographic variation were analyzed using 2 methods. First, we used stepwise multiple regression (with forward elimination and p-values of 0.05 for entry and removal of variables) to examine the relationship between the abundance of foraging auklets and variation in peak current strength among transects. In these analyses, the dependent variable was the total number of each species counted along the standard transect. Time of day was included as a second independent variable in these analyses to remove possible temporal trends that might confound relationships between oceanography and auklet abundance at sea
Species-specific responses to oceanographic variation within each transect were examined using simple correlation analysis. For each transect, we computed the Pearson correlation coefficient between numbers of each species and the convergence rate in the $10 \mathrm{~m}$ depth stratum in each $2 \mathrm{~min}$ bin for which ADCP data were available. Positive correlations indicate that numbers tended to be higher in areas of surface convergence, and negative correlations indicate that numbers tended to be higher in areas of surface divergence. We used a parametric 1-way ANOVA to test for differences in this measure among the species, and then constructed $95 \%$ confidence intervals to test the hypothesis that the mean correlation coefficient for each sample differed from zero. For these analyses, sample sizes refer to the numbers of transects for which correlations were computed.

\section{RESULTS}

\section{Physical processes}

The tidal cycle at nearby Ogliuga Island during both sampling periods was primarily diurnal. Low water slack occurred at around noon and high water slack around midnight. Thus, ebb tides occurred in the morning and flood in the afternoon. The highest high tides were about $+120 \mathrm{~cm}$ and the lowest lows were about $-30 \mathrm{~cm}$. The tide ebbed from high to low in about $7 \mathrm{~h}$ but required $12 \mathrm{~h}$ to flood. High water slack lasted about $4 \mathrm{~h}$ and low water slack about $2 \mathrm{~h}$. Tidal currents through the pass exceeded $2 \mathrm{~m} \mathrm{~s}^{-1}$ during the height of flood and ebb and produced 1 to $2 \mathrm{~m}$ standing waves above the crest of the sill. Upstream of the sill, when the tide was flowing strongly, there was an area of smooth water that appeared slick. Downstream of the sill, the water was choppy, with frequent boils surfacing at irregular intervals. This region terminated in a strong convergence line at which flotsam accumulated.

The upper $20 \mathrm{~m}$ of the water column in the Delarof region was stratified, with tidally generated frontal regions to the south or north of the ridge, depending on the phase of the tidal cycle. During high water slack and the early stages of ebb tide, a time series of CTD measurements at a fixed station showed the tidal convergence front drifting south (Fig. 2). At that time, the front was to the north of the ridge between $51.60^{\circ}$ and $51.62^{\circ} \mathrm{N}$, and the stratified side of the front extended southward over the sill. The water column north of the front had weak stratification. Shortly after the time series was completed, a CTD transect along the standard line showed that the front had drifted south and was over the top of the sill (Fig. 3). The isolines were 
Stations 80-105, 19 July 1993, Time Series
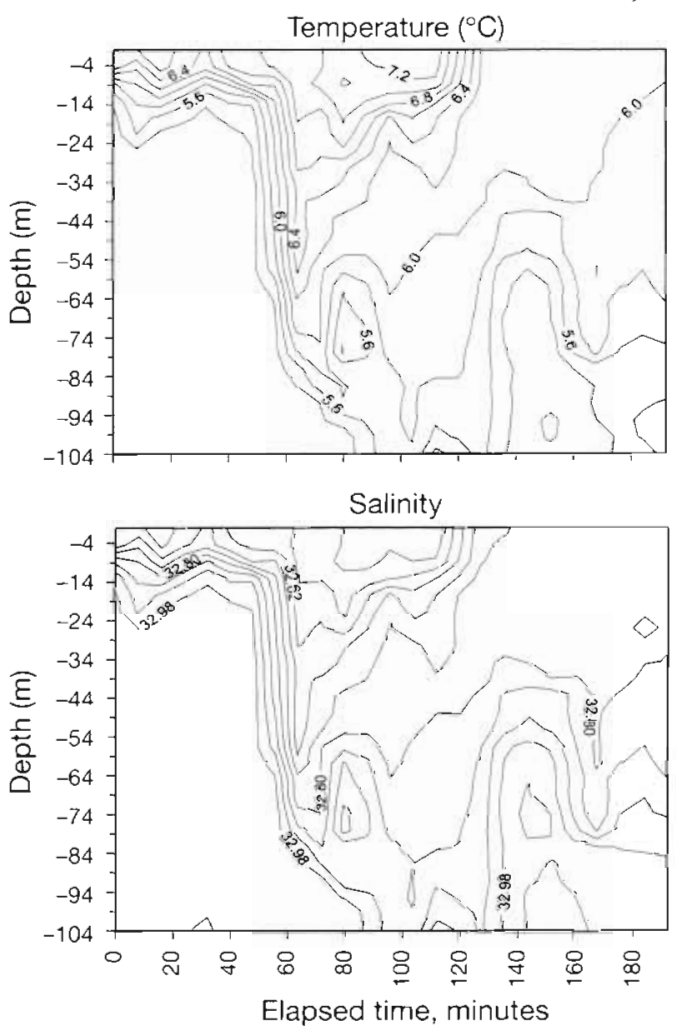

Chlorophyll $\left(\mu \mathrm{g}^{-1}\right)$
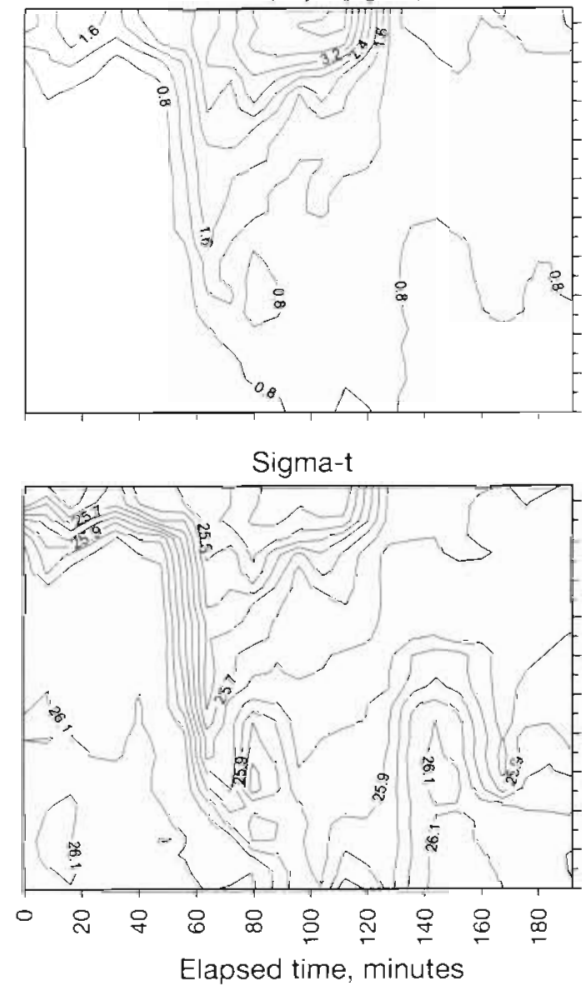

Fig. 2. Results of a time series of CTD casts taken at $51.61^{\circ} \mathrm{N}$ between $21: 20$ and $00: 34 \mathrm{~h}$ on 18-19 July 1993 during high water slack tide and the beginning of the ebb tide. The $x$-axis is in minutes since the start of the time series

Stations 106-114, 19 July 1993
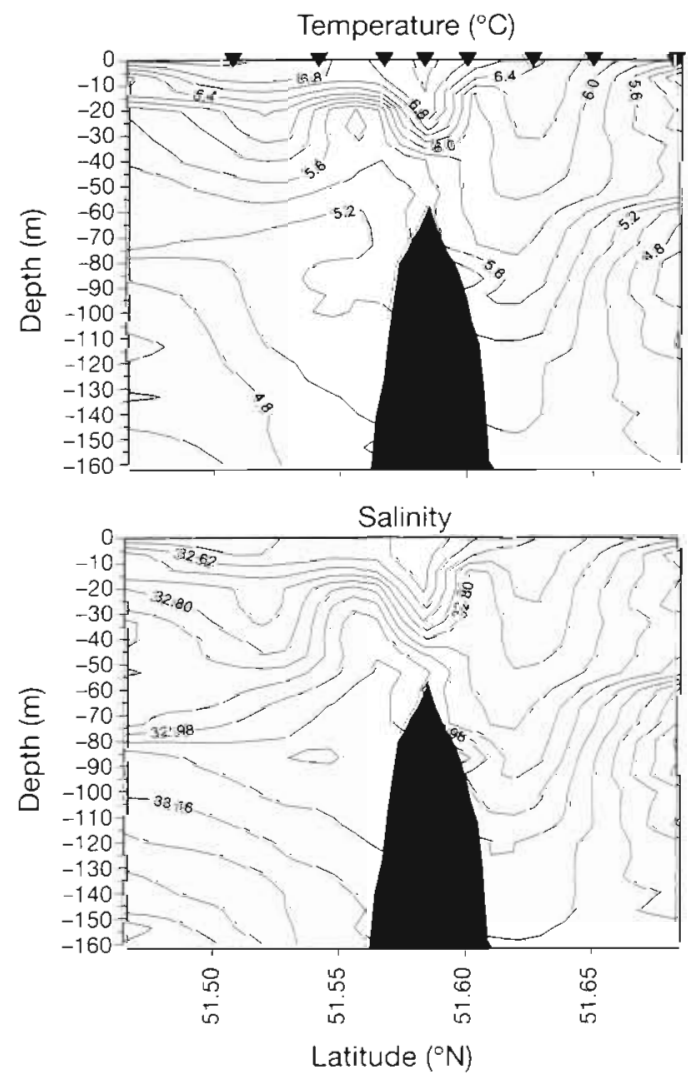

Chlorophyll $\left(\mu \mathrm{g} \mathrm{I}^{-1}\right)$
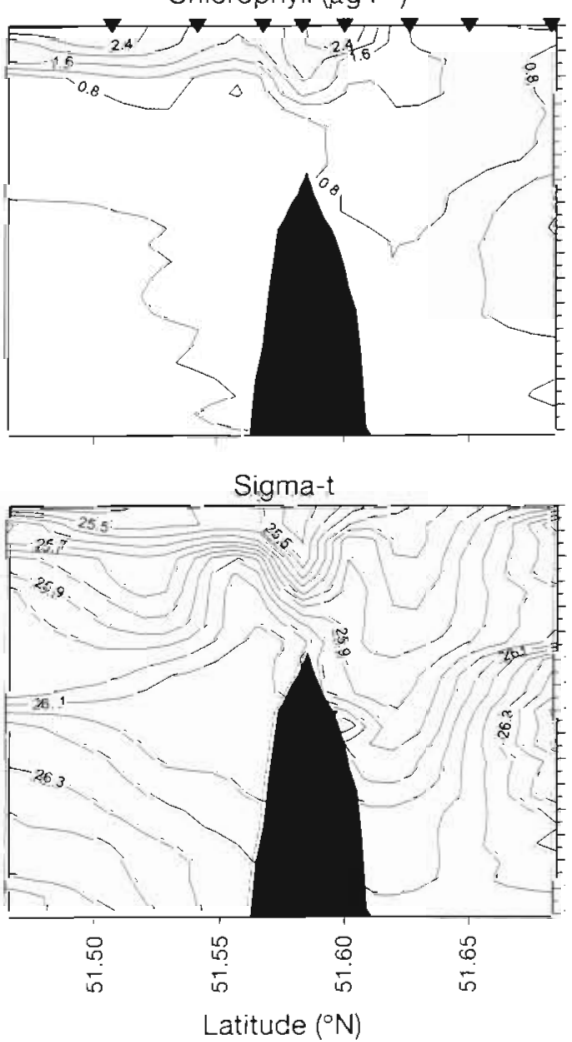

Fig. 3. A CTD crosssection along the standard transect taken between $01: 15$ and $04: 40 \mathrm{~h}$ on 19 July 1993, at the beginning of the ebb tide. The frontal area that was north of the sill in Fig. 2 has now shifted southward over the sill and is changing form in the south-flowing current 

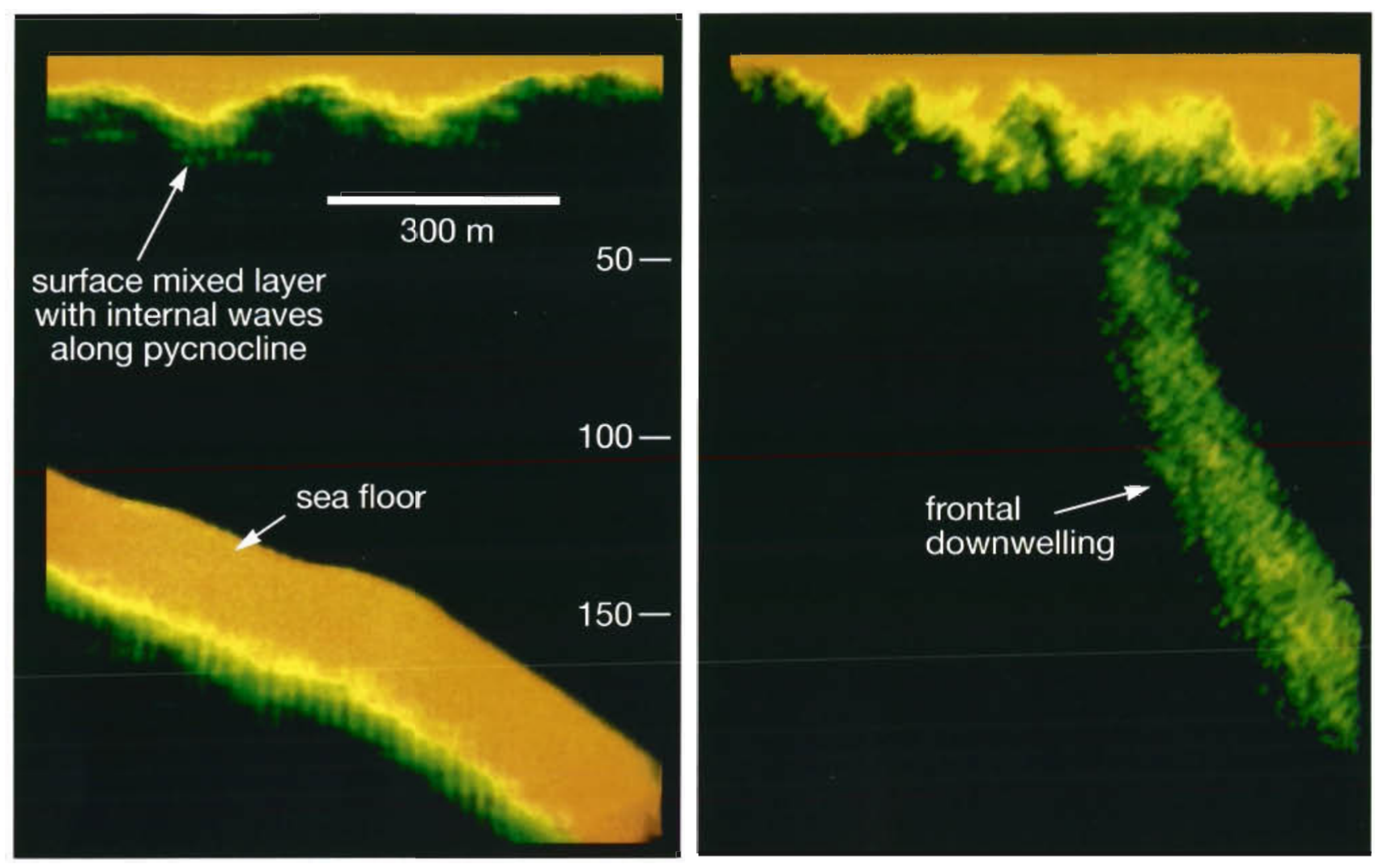

Fig. 4. Photos of images on the wheelhouse depth sounder $(38 \mathrm{kHz})$ when the gain was turned up to reveal backscatter in the upper water column. Left: Wave-like undulations along the bottom of the mixed layer at a depth of about 25 mi as the watei passes to the rignt during a strong flood tide. The profile of the sill is at the bottom of the picture. Right: Further north, in the area of the principal tidal convergence, this image shows backscattering extending from the upper water column to below $150 \mathrm{~m}$. We interpret this backscatter as an indication of the entrainment of bubbles and biomass in the frontal downwelling

bent upward on the north side of the sill and stratified water occurred at the northern extreme of the line. Thus, the position of the front relative to the sill and the distribution of stratified water was a function of the stage in the diel tidal cycle. The frontal region was pushed northward or southward over the sill with flood and ebb tide, respectively. The stratification and the position of the front was evident on the ship's depth sounder when the gain was maximized (Fig. 4).

ADCP data from transects conducted during periods of strong flow revealed the presence of a zone of intense surface divergence just upstream of the ridge and a zone of intense surface convergence just downstream of the ridge. An example is shown in Fig. 5 from a transect conducted during strong (peak $=2 \mathrm{~m} \mathrm{~s}^{-1}$ ) northward flow on 20 July 1993. The divergence zone south of the ridge resulted from the acceleration of current velocities between the south end of the transect and the sill (Fig. 5, upper left), and caused apparent upwelling of sound-scattering material over the southern slope of the ridge (Fig. 5, lower left). Current velocities decelerated on the north side of the ridge, and a strong convergence zone was evident at about $51.62^{\circ} \mathrm{N}$.
The region of surface convergence was accompanied by an irregular band of intense sound scattering from the surface down to $20-40 \mathrm{~m}$ depth (Fig. 5, lower left). Elevated zooplankton densities in nets $3,4,5$ and 6 indicate the potential concentrating effect of the surface convergences on zooplankton north of the ridge (Fig. 5, lower right).

Embedded within the broad region of convergence downstream of the sill were periodic small-scale convergence and divergence zones (Fig. 6). The spatial scale of these features was often too small to be detected by the ADCP, which integrated data over 2 min and thus averaged flow over a larger area than that occupied by individual flow features. Nevertheless, the presence of these features was revealed by small-scale intense fluctuations in salinity and temperature (e.g. Fig. 5, top and middle right), as well as by surface properties of the water as evident to shipboard observers. In many instances, we observed aggregations of flotsam and foam in narrow lines above the small-scale convergences. Acoustic observations (e.g. Fig. 4) and CTD data (e.g. Fig. 3) suggested that smallscale internal waves were present in the upper $15 \mathrm{~m}$ of 

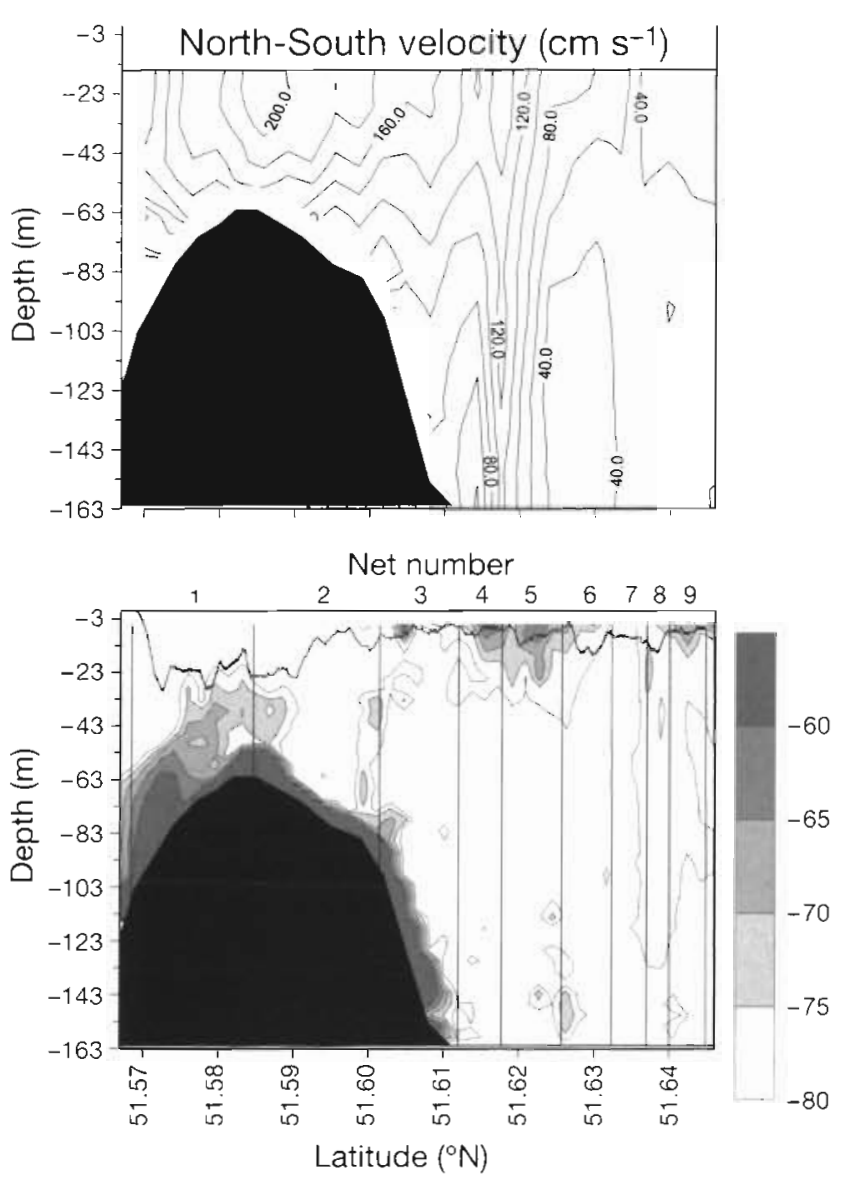
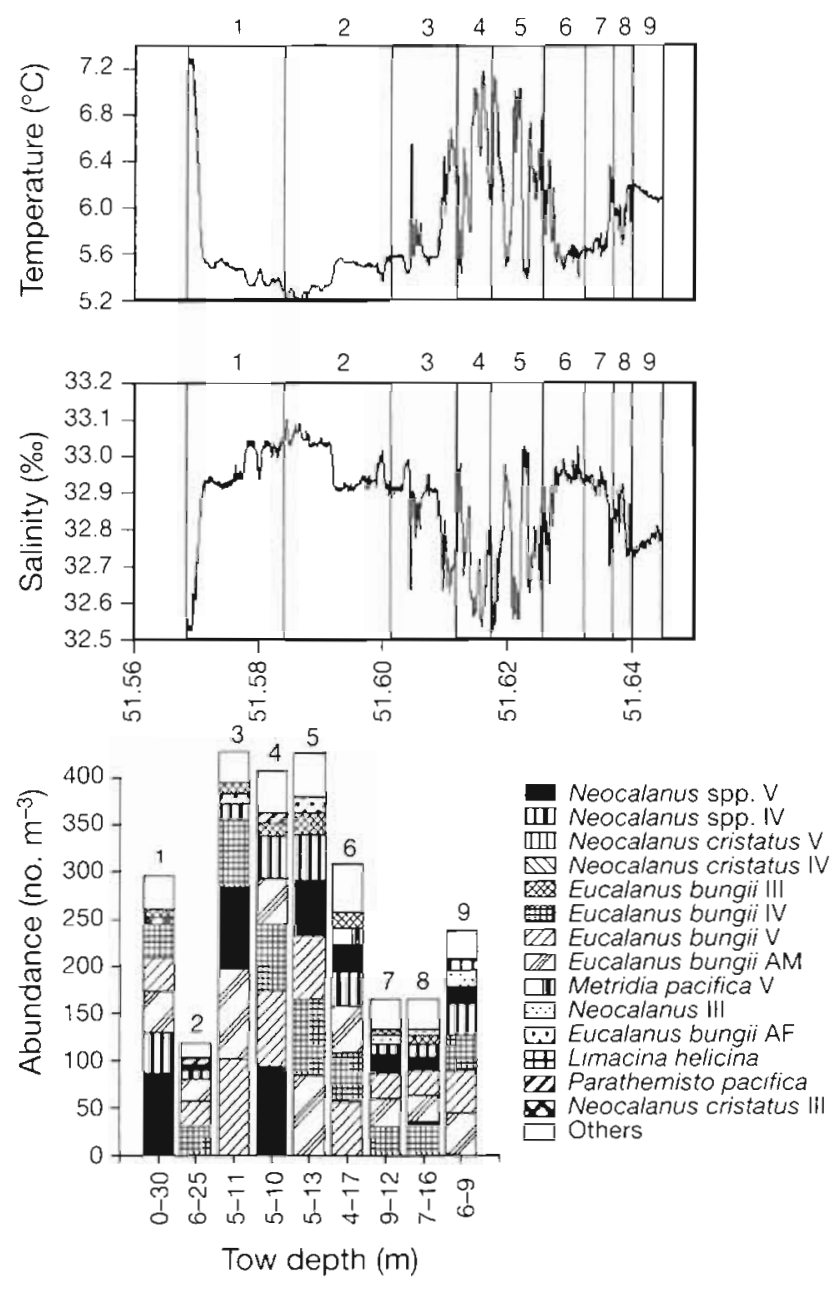

Fig. 5. An example of the suite of data obtained during MOCNESS tows through the convergence zone on a flood tide. Upper left: Results from the ADCP showing strong northward flowing currents over the sill, and a strong convergence zone between $51.61^{\circ}$ and $51.62^{\circ} \mathrm{N}$. Lower left: Echogram from the $420 \mathrm{kHz}$ echosounder on $20 \mathrm{July} 1993$, showing strong echo returns from the upper water column and the presence of strong convergences downstream of the pass. The jagged horizontal line is the path of the MOCNESS deployed simultaneously with the echosounder. Right: Records of temperature, salinity and zooplankton abundance by taxa obtained from the MOCNESS. Note the rapid, large variations in temperature and salinity as the net passed between convergence and divergence zones. Neocalanus spp. IV and V include $N$. plumchrus/flemengeri and were the principal prey of the least auklets

the water column in the lee of the sill, and were likely responsible for the small-scale convergence and divergence features.

The coupled system of convergences and divergences mixed water from above and below the pycnocline. In Fig. 5, comparisons of salinity and temperature values from the start of the transect, from the deepest part of the MOCNESS track at about $51.58^{\circ} \mathrm{N}$, and from the north end of the transect confirm that mixing occurred.

\section{Zooplankton distributions and abundances}

Maximum sound scattering during all 3 tidal conditions occurred in the surface, with the amount of scat- tering decreasing as a function of depth down to $55 \mathrm{~m}$ (Fig. 7). Volume scattering in excess of $-68 \mathrm{~dB}$ cannot be attributed to zooplankton. When volume scattering in excess of $-68 \mathrm{~dB}$ occurred at the surface during flood and ebb tides, it was caused primarily by entrained bubbles, particularly on the downstream side of the ridge. When it occurred near the bottom or in midwater, strong acoustic return was probably primarily the result of scattering from fish. Intense scattering very close to the bottom on the slope of the ridge may also include some reflection of the bottom of the sound cone side lobe. The very irregular depth distribution in scattering intensity in the upper $50 \mathrm{~m}$ is indicative of instability in the depth of the pycnocline.

Upwelled water, as identified by CTD measurements from individual MOCNESS tows, produced lower 


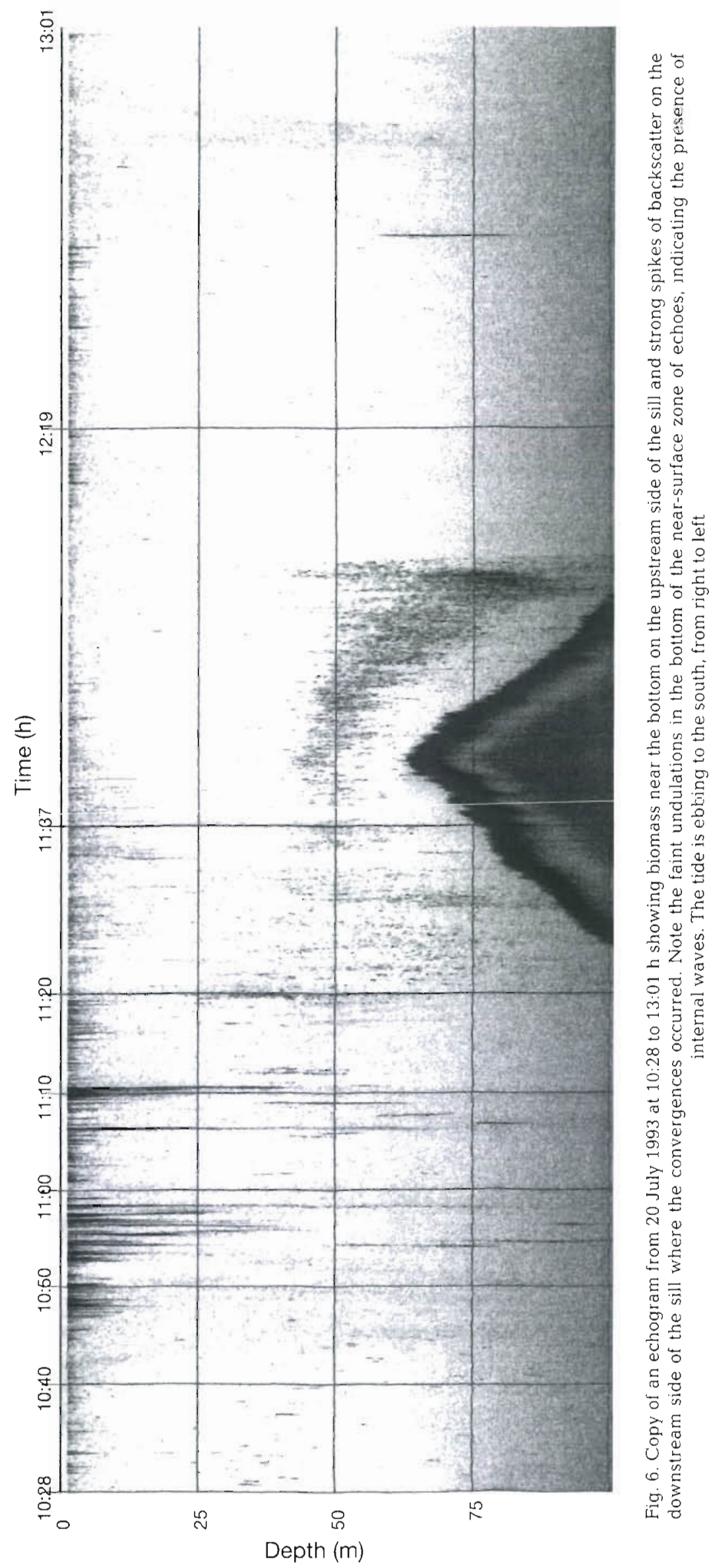

levels of acoustic backscattering than did surface water because of a lack of bubbles and lower densities of zooplankton. The upward slope of the scattering contours on the north side of the ridge during ebb tide are indicative of upwelling of deep water over the ridge as water flowed from north to south (Fig. 7c). Elevated scattering in the upper $25 \mathrm{~m}$ was also observed south of the ridge during slack tides. During flood tide conditions, we observed the packing of scattering contours into the upper $10 \mathrm{~m}$ on the south side of the ridge. Downstream of the sill, on the north side, the near-surface layer of volume backscattering was interrupted by a series of sharp spikes of acoustic return that penetrated 20 to $50 \mathrm{~m}$ deep, beyond which the acoustic return dropped to levels intermediate between those south of the sill in the upper mixed layer and those below the pycnocline (Figs. 6\&7a). Conditions outside tidal influences south of the ridge were probably not observed during the flood tide series since the transects began at $51.53^{\circ} \mathrm{N}$.

Correlations between $420 \mathrm{kHz}$ volume backscattering and depth were negative within the upper $20 \mathrm{~m}$ of the water column in both July $\left(\mathrm{r}_{\mathrm{p}}=-0.38, \mathrm{n}=50\right.$ transects, $\mathrm{p}<$ $0.05)$ and August $\left(r_{p}=-0.52, n=26\right.$ transects, $p<0.05$ ), primarily because of the intense scattering associated with surface convergences. No significant correlations were evident between volume scattering and zooplankton biomass (July: $r_{p}=0.17, n=$ 50 transects, $p>0.05$; August: $r_{p}=-0.36, n=$ 26 transects, $p>0.05$ ), presumably due to the confounding effects of scattering by entrained bubbles in the convergence zones.

The dominant taxa of zooplankton obtained in the MOCNESS tows were Neocalanus plumchrus/flemengeri and Eucalanus bungii (Table 1). The abundances and biomasses of most zooplankton taxa were higher in July than they were in August 1993. with the average abundance in August of Neocalanus spp. and E. bungii less than half of what they were in July. Differences between the abundances of NeoCalanus spp. and E. bungii in the upper and lower water column were greater in July than they were in August.

In July, the biomass and abundance of zooplankton, as determined from MOC- 

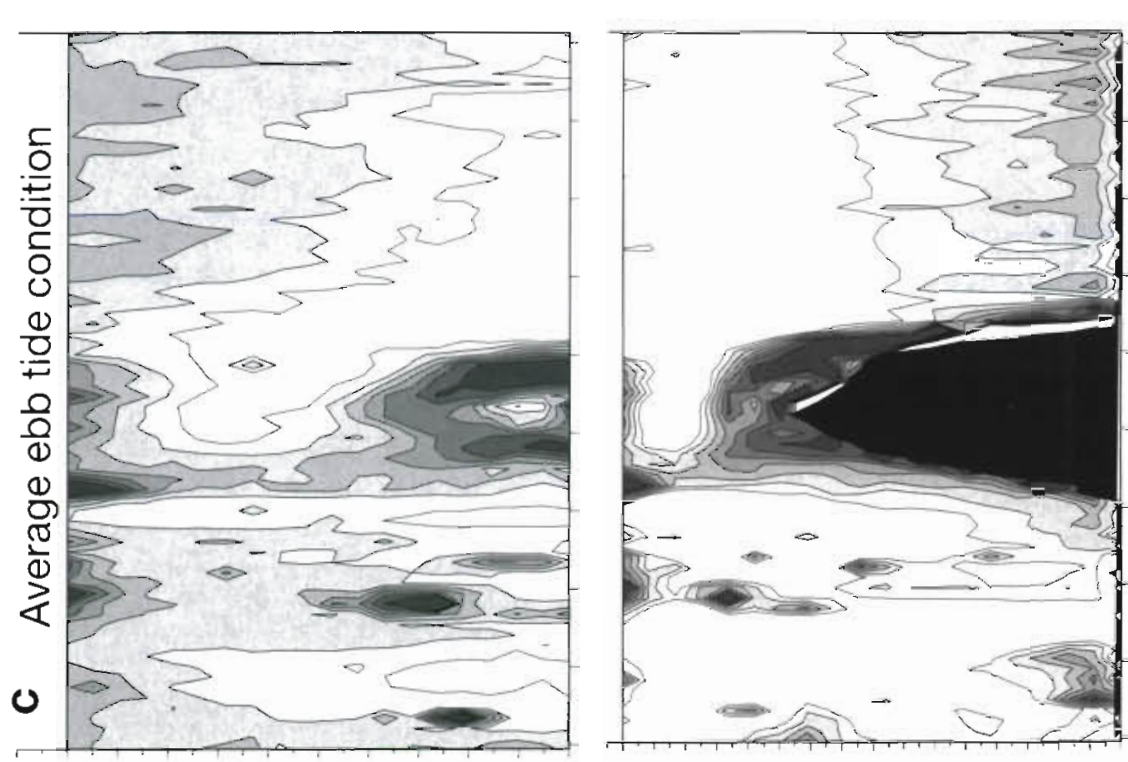

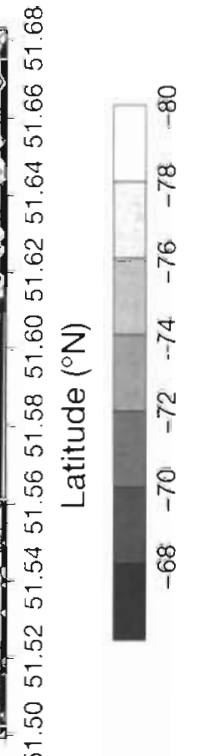

苟 的
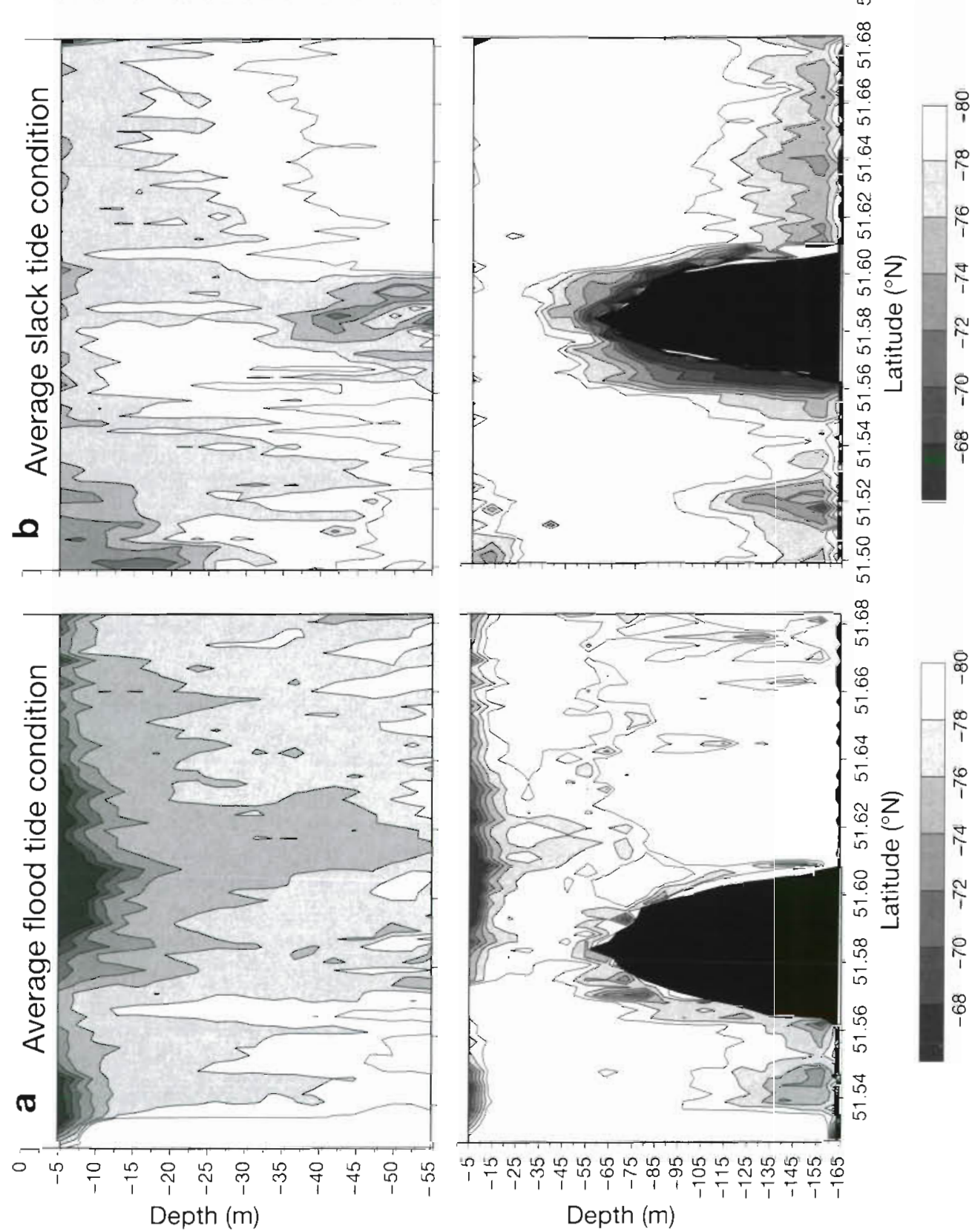

吾 $\frac{1}{0}$

戈苛

马

号至

농

워

을

롱

总兽

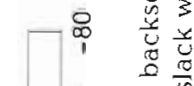

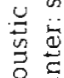

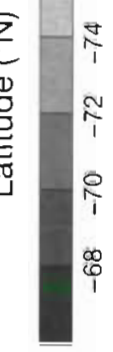

$\pi$

㠃苛

응

용몬

. 
Table 1. Relative abundance of the dominant taxa from MOCNESS samples taken in the Delarof Pass region. If average depth of the tow was $<20 \mathrm{~m}$, it was assigned to the upper $20 \mathrm{~m}$, if $>20 \mathrm{~m}$, it was assigned to the $20-40 \mathrm{~m}$ category. Neocalanus spp. refers to a mixture of $N$. plumchrus and $N$. flemengeri

\begin{tabular}{|c|c|c|c|c|c|c|c|c|c|c|c|c|}
\hline \multirow{3}{*}{ Taxon } & \multicolumn{6}{|c|}{5 to 19 July } & \multicolumn{6}{|c|}{5 to 6 August } \\
\hline & \multicolumn{3}{|c|}{ Upper $20 \mathrm{~m}(\mathrm{n}=45)$} & \multicolumn{3}{|c|}{$20-40 m(n=19)$} & \multicolumn{3}{|c|}{ Upper $20 \mathrm{~m}(\mathrm{n}=26)$} & \multicolumn{3}{|c|}{$20-40 m(n=6)$} \\
\hline & $\begin{array}{l}\text { no } \\
\mathrm{m}^{-3}\end{array}$ & $\begin{array}{l}\% \text { of } \\
\text { no. }\end{array}$ & $\begin{array}{l}\% \text { bio- } \\
\text { mass }\end{array}$ & $\begin{array}{l}\text { no. } \\
m^{-1}\end{array}$ & $\begin{array}{l}\% \text { of } \\
\text { no. }\end{array}$ & $\begin{array}{l}\text { \% bio- } \\
\text { mass }\end{array}$ & $\begin{array}{l}\mathrm{no}^{-} \\
\mathrm{m}^{-3}\end{array}$ & $\begin{array}{l}\% \text { of } \\
\text { no. }\end{array}$ & $\begin{array}{l}\% \text { bio- } \\
\text { mass }\end{array}$ & $\begin{array}{l}\text { no. } \\
\mathrm{m}^{-3}\end{array}$ & $\begin{array}{l}\% \text { of } \\
\text { no. }\end{array}$ & $\begin{array}{c}\% \text { bio- } \\
\text { mass }\end{array}$ \\
\hline Neocalanusspp. IV \& V & 59.13 & 20.42 & 24.88 & 22.69 & 10.75 & 12.70 & 16.27 & 20.99 & 28.15 & 13.20 & 15.19 & 17.75 \\
\hline Neocalanusspp. Ill & 15.04 & 5.19 & 0.85 & 8.11 & 3.84 & 0.71 & 2.58 & 3.33 & 0.48 & 1.88 & 2.16 & 0.30 \\
\hline$N$. cristatus $\mathrm{V}$ & 0.22 & 0.08 & 0.72 & 0.14 & 0.07 & 0.72 & 0.34 & 0.43 & 3.77 & 0.53 & 0.61 & 4.86 \\
\hline$N$ cristatus IV & 0.41 & 0.14 & 0.25 & 1.43 & 0.68 & 1.57 & 0.46 & 0.59 & 1.15 & 0.80 & 0.92 & 1.46 \\
\hline Eucalanus bungii ad. & 51.76 & 17.87 & 30.73 & 30.53 & 14.47 & 26.58 & 9.39 & 12.11 & 20.04 & 10.53 & 12.12 & 18.10 \\
\hline E. bungii IV \& V & 103.96 & 35.89 & 32.82 & 89.41 & 42.36 & 38.69 & 19.42 & 25.05 & 25.09 & 17.67 & 20.33 & 12.92 \\
\hline Metridia pacifica ad. & 0.48 & 0.17 & 0.10 & 2.05 & 0.97 & 0.69 & 0.79 & 1.02 & 0.49 & 1.13 & 1.30 & 0.51 \\
\hline Calanus pacificus V & 1.67 & 0.58 & 0.17 & 0.56 & 0.26 & 0.11 & 0.32 & 0.41 & 0.09 & 0.44 & 0.50 & 0.10 \\
\hline Euphausiid furcilia & 3.75 & 1.29 & 0.69 & 7.42 & 3.51 & 3.32 & 0.78 & 1.01 & 0.31 & 0.99 & 1.14 & 0.50 \\
\hline Parathemisto pacifica & 5.65 & 1.95 & 1.30 & 5.59 & 2.65 & 3.33 & 2.48 & 3.20 & 2.45 & 3.12 & 3.59 & 3.93 \\
\hline Oikopleurasp. & 3.54 & 1.22 & 0.49 & 2.20 & 1.04 & 0.44 & 0.34 & 0.44 & 0.13 & 0.29 & 0.33 & 0.09 \\
\hline Sagitta elegans & 5.50 & 1.90 & 2.74 & 4.60 & 2.18 & 6.32 & 2.19 & 2.83 & 5.57 & 2.78 & 3.20 & 5.80 \\
\hline Limacina helicina & 4.46 & 1.54 & 0.42 & 1.41 & 0.67 & 0.22 & 6.69 & 8.63 & 1.09 & 13.61 & 15.67 & 1.22 \\
\hline Others & 34.06 & 11.76 & 3.84 & 34.96 & 16.56 & 4.61 & 15.47 & 19.96 & 11.19 & 19.94 & 22.95 & 32.46 \\
\hline
\end{tabular}

Table 2. Correlation coefficients between the density of major taxa and sigma-t and depth in Delarof Pass during 1993. For July, $N=50$, the correlation coefficient between sigma-t and depth was 0.69 , and coefficients $>0.246$ or $<-0.246$ are significantly different from 0. For August, $\mathrm{N}=33$, the correlation coefficient between sigma-t and depth was 0.38 , and coefficients $>0.344$ or $<-0.344$ are significantly different from 0 . Neocalanus spp. refers to a mixture of $N$. plumchrus and $N$. flemengeri

\begin{tabular}{|c|c|c|c|c|c|c|c|c|}
\hline \multirow[t]{3}{*}{ Taxon } & \multicolumn{4}{|c|}{ July } & \multicolumn{4}{|c|}{ August } \\
\hline & \multirow{2}{*}{\multicolumn{2}{|c|}{$\begin{array}{l}\text { Sigma-t } \\
\text { Biomass Abundance }\end{array}$}} & \multicolumn{2}{|c|}{ Depth } & \multicolumn{2}{|c|}{ Sigma-t } & \multicolumn{2}{|c|}{ Depth } \\
\hline & & & Biomass & Abundance & Biomass & Abundance & Biomass & Abundance \\
\hline Neocaläruis spp. IV \& V & -0.44 & -0.49 & -0.40 & -0.40 & -0.20 & -0.38 & -0.14 & 0.03 \\
\hline Neocalanus spp. III & -0.26 & -0.37 & -0.13 & -0.10 & -0.09 & -0.24 & 0.12 & 0.02 \\
\hline$N$ cristatus $V$ & -0.11 & -0.14 & -0.17 & -0.17 & 0.52 & 0.43 & 0.12 & 0.07 \\
\hline$N$ cristatus IV & 0.36 & 0.42 & 0.41 & 0.38 & 0.21 & 0.19 & 0.12 & 0.03 \\
\hline Eucalanus bungii ad. & -0.40 & -0.27 & -0.38 & -0.28 & -0.06 & 0.10 & 0.07 & 0.11 \\
\hline E. bungil V \& IV & -0.23 & -0.06 & -0.22 & -0.08 & 0.02 & 0.02 & 0.04 & 0.07 \\
\hline Metridia pacifica ad. & 0.38 & 0.35 & 0.36 & 0.31 & -0.11 & -0.04 & 0.03 & 0.14 \\
\hline Calanus pacificus $\mathrm{V}$ & -0.34 & -0.41 & -0.21 & -0.24 & -0.21 & -0.21 & 0.07 & 0.08 \\
\hline Euphausidd furcilia & 0.51 & 0.33 & 0.45 & 0.26 & 0.18 & -0.02 & 0.58 & 0.46 \\
\hline Parathemisto pacifica & 0.21 & -0.08 & 0.31 & -0.01 & 0.35 & -0.02 & 0.50 & 0.38 \\
\hline Oikopleura sp. & -0.12 & -0.06 & 0.02 & 0.15 & -0.61 & -0.68 & -0.03 & 0.00 \\
\hline Sagitta elegans & 0.20 & -0.17 & 0.24 & 0.00 & 0.16 & 0.02 & 0.10 & 0.45 \\
\hline Limacina helicina & -0.53 & -0.69 & -0.35 & -0.55 & -0.45 & -0.58 & 0.21 & 0.22 \\
\hline All taxa & -0.35 & -0.26 & -0.32 & -0.16 & -0.01 & -0.33 & 0.13 & 0.18 \\
\hline
\end{tabular}

NESS tows, were more strongly correlated with water mass than with depth when using sigma-t as a proxy for water mass (Table 2). In July, Neocalanus plumchrus/flemengeri copepodites IV and V were increasingly abundant toward the surface, whereas $N$. cristatus copepodite stages IV and V and euphausiid furcilia increased in abundance with depth. In August, correlations of total biomass and abundance with depth and sigma-t were not significant, and the distributions of the major taxa of copepods showed little relationship to depth (Tables 1 \& 2), possibly because there was greater mixing in August than in July, as indicated by the weaker correlation between depth and sigma- $t$ in August (0.38) than in July (0.69).
Four MOCNESS deployments, 2 in July and 2 in August, were performed through the pass during flood or ebb tides, and sampled near-surface waters with 31 nets, of which 17 were in convergence zones as determined by the high acoustic return $(>-68 \mathrm{~dB})$ that originated from entrained bubbles (Table 3). Mean densities of Neocalanus plumchrus/flemengeri copepodites IV and V were higher in nets towed in convergences than in those towed outside areas of convergence (Mann Whitney $U$-test, $U=58, p=0.025$ ). Additionally, high densities ( $\geq 50$ individuals $\mathrm{m}^{-3}$ ) of N. plumchrus/flemengeri copepodites IV and $V$ were more frequently encountered in convergences than in adjacent surface waters $\left(\chi^{2}=5.0, \mathrm{df}=1, \mathrm{p}=0.025\right)$. A 
Table 3. Densities (individuals $\mathrm{m}^{-3}$ ) of Neocalanus plumchrus/flemengeri caught in MOCNESS tows in surface waters in areas of convergence and in areas lacking strong convergence, as determined by acoustic evidence of bubble entrainment. $X_{n c}=$ mean density when no convergence present; $X_{c}=$ mean density when convergence present

\begin{tabular}{|c|c|c|c|c|c|c|c|}
\hline Tow & \multicolumn{3}{|c|}{ Strong convergence lacking } & \multicolumn{3}{|c|}{ Strong convergence present } & $\begin{array}{c}\text { No. of nets from convergences } \\
\text { with } X_{c}>X_{n c}\end{array}$ \\
\hline 11 & 3 & 2 & 64.4 & 5 & 3 & 68.3 & 2 \\
\hline 12 & 3 & 0 & 25.3 & 5 & 5 & 93.6 & 5 \\
\hline 30 & 4 & 0 & 17.4 & 4 & 1 & 51.0 & 3 \\
\hline 31 & 4 & 0 & 5.5 & 3 & 0 & 11.2 & 3 \\
\hline Total & 14 & 2 & & 17 & 9 & & 12 \\
\hline
\end{tabular}

third MOCNESS deployment in July was taken during maximum flood and sampled in the convergence region, as indicated by elevated sound scattering. However, zooplankton densities in the 3 nets towed within areas of convergence were minimal and did not differ from tows made outside the convergences. Examination of the MOCNESS CTD record for that tow indicated that the water mass for the entire tow, including that in the convergence region, was from below the pycnocline. The above results indicate that convergences tended to concentrate prey if water in the convergence zones was from above the pycnocline. In contrast, zooplankton densities were minimal when water masses in the convergences were from below the pycnocline.

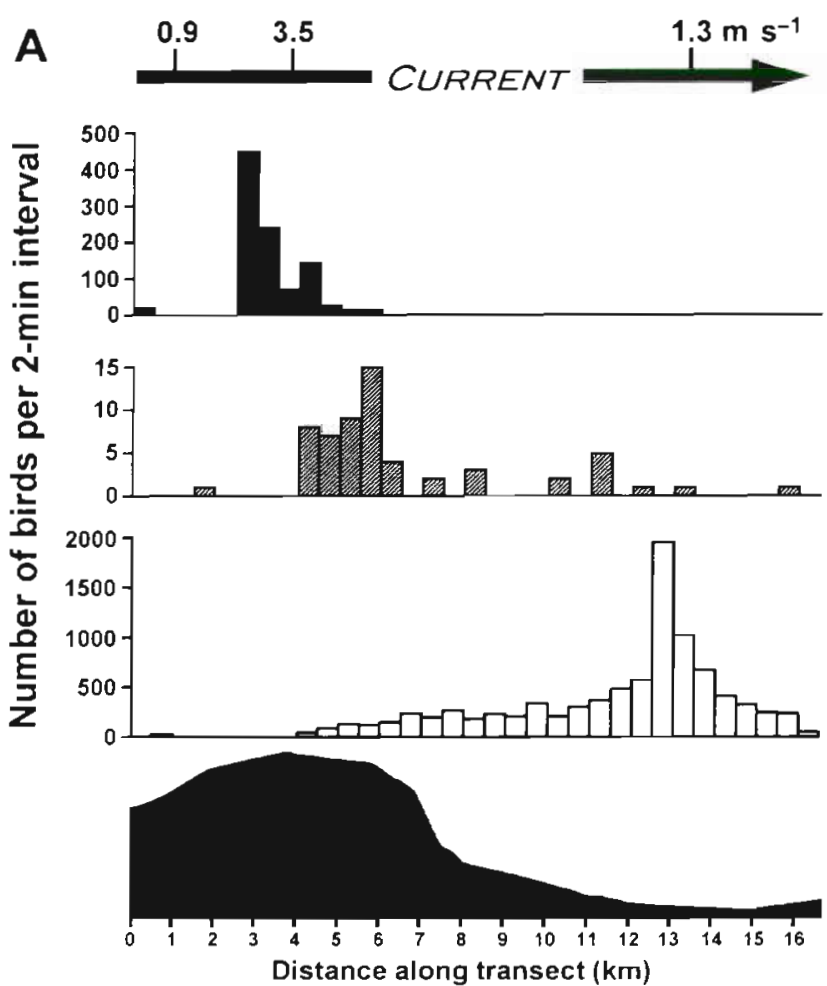

\section{Distribution of auklets}

The 3 auklet species showed distinct patterns of spatial separation along the standard transect (Figs. 8 \& 9). Examination of spatial distributions within individual transects showed the crested auklets occurred upstream from parakeet and least auklets significantly more frequently than expected, and least auklets occurred downstream from the other species significantly more frequently than expected (Table 4). When the direction of the tidal current reversed, the ordering of the 3 species also reversed. Most dramatically, when tidal currents were strong, thousands of crested auklets would repeatedly dive on the up-
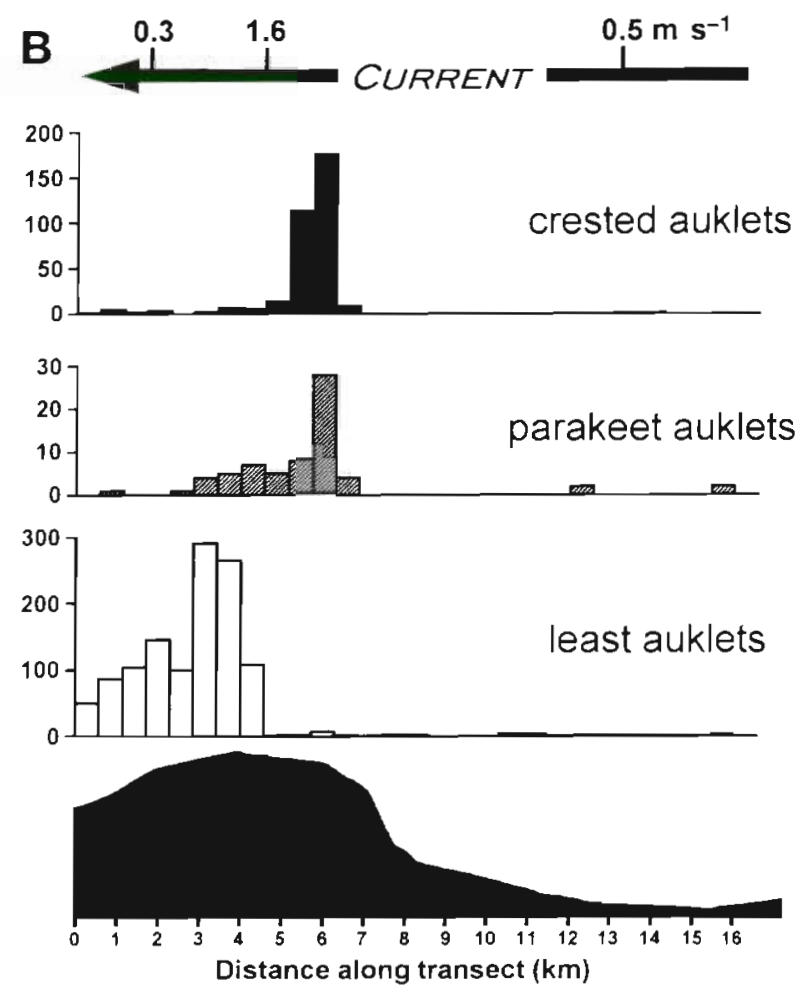

Fig. 8. Aethia pusilla, A. cristatella, A. psittacula. (A) Distribution of crested, parakeet and least auklets during a transect conducted on 19 July 1993 during strong northward flow. The bottom panel is a profile of the bathymetry. (B) Distribution of crested. parakeet and least auklets during a strong ebb tide (18 July 1993) 

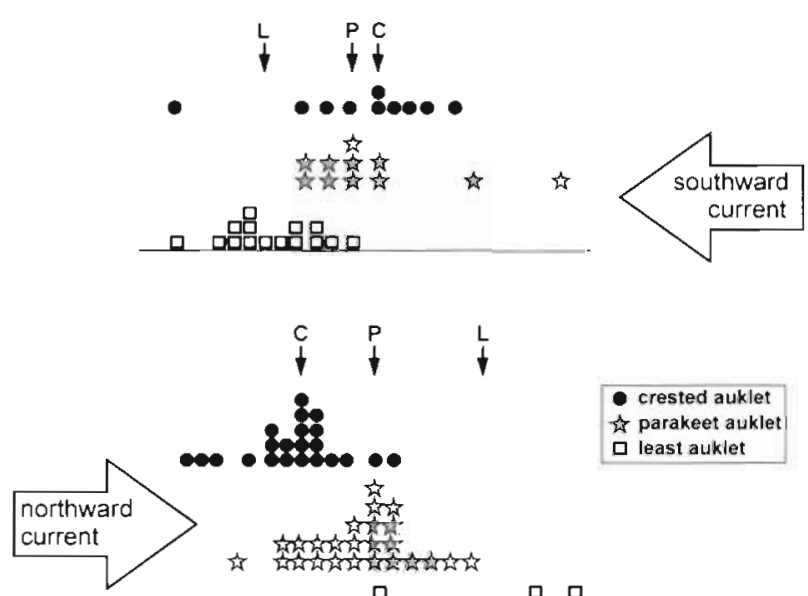

- crested auklet 5. parakeet auklet| Ieast auklet

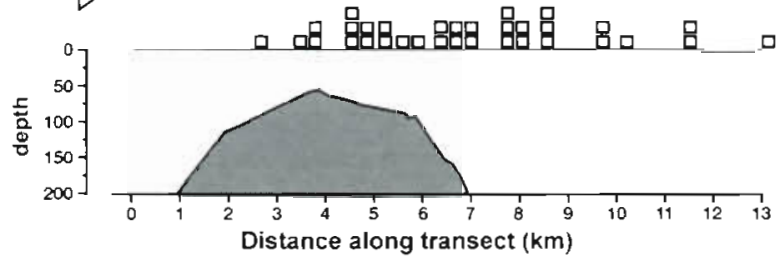

Fig. 9. Patterns of spatial segregation of 3 species of auklets in relation to current direction. Each point denotes the modal location of 1 species during 1 transect. Vertical dotted line shows the location where the water column is shallowest (depth $=55 \mathrm{~m}$ ). Arrows mark the median of each species' dis-

tribution. The bottom panel shows the profile of the sill

stream side of the sill starting about $2 \mathrm{~km}$ from the region with standing waves over the sill crest. As the crested auklets reached the area of slick water in front of the standing waves, they would emerge from the water in groups of tens to hundreds and fly back up stream to dive again. In contrast, hundreds to thousands of least auklets congregated on the water downstream of the sill, usually between boils and sometimes around the edges of boils. Parakeet auklets were most often found in the region of standing waves over the top of the sill.

Statistical analyses of data from all transects combined confirmed that the 3 auklet species occurred predictably in different areas along the standard transect. During periods of northward flow, variances in modal location were heterogeneous among the 3 species (Bartlett's test, $\chi^{2}=25.6, d f=2, p \ll 0.0001$ ) (Fig. 9). Modal locations differed significantly among the 3 species (Kruskal-Wallis ANOVA, $H=$ 43.2, $\mathrm{p}<10^{-9}$ ), and multiple comparisons indicated significant differences between each pair of species (all $p<0.001$ ). During periods of southward flow, variances in modal location were homogeneous among
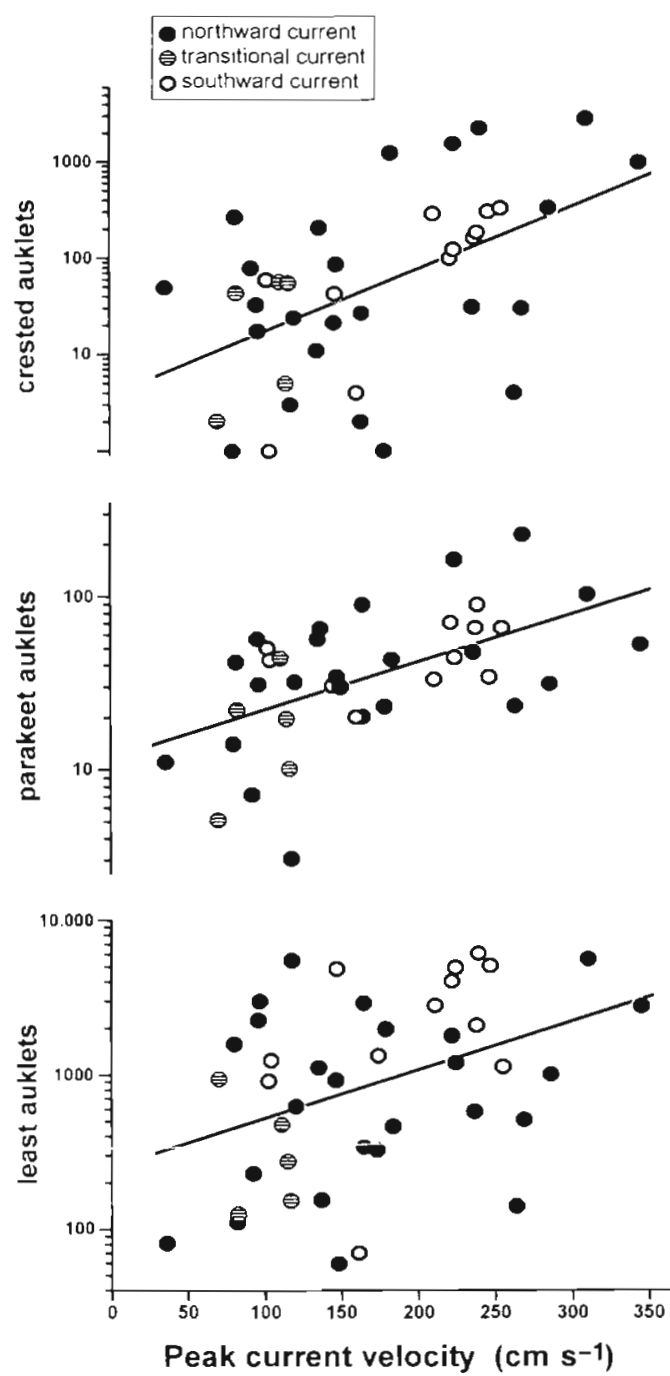

Fig. 10. Relationships between numbers of auklets present on transects and peak current speed along each transect. A logarithmic transform was used to normalize the distribution of auklet counts. To accommodate the logarithmic abundance scale, 1 has been added to all auklet counts. A.ll regressions significant at $\mathrm{p} \leq 0.001$ (see Table 5)

Table 4. Aethia pusilla, A. cnstatella, A psittacula. Patterns in the ordering of modal locations of the 3 auklet species within individual transects.

P-values are from binomial tests (ties were not included in analyses)

\begin{tabular}{|lrc|}
\hline Distributional pattern within transects & $\mathrm{n}$ & $\mathrm{p}$ \\
\hline Least auklets upstream of crested auklets & 1 & \\
Least auklets downstream of crested auklets & 29 & $<10^{-7}$ \\
Ties & 1 & \\
Least auklets upstream of parakeet auklets & 9 & \\
Least auklets downstream of parakeet auklets & 26 & 0.0030 \\
Ties & 1 & \\
Crested auklets upstream of parakeet auklets & 21 & \\
Crested auklets downstream of parakeet auklets & 5 & 0.0012 \\
Ties & 3 & \\
\hline
\end{tabular}


Table 5. Relationships between the abundance of auklets along the standard transect and both peak current speed (as measured by ADCP) and time of day. Values shown are standard coefficients from stepwise multiple linear regression models, with log-transformed $[\ln (x+1)]$ total counts of each species as the dependent variables. (-) Variables that were forced out of the models. Sample sizes indicate numbers of transects for which ADCP data were available. $\cdots p<0.001$

\begin{tabular}{|c|c|c|c|}
\hline Independent variable & $\begin{array}{l}\text { Least } \\
\text { auklet } \\
(\mathrm{n}=42)\end{array}$ & $\begin{array}{l}\text { Crested } \\
\text { auklet }^{\mathrm{b}} \\
(\mathrm{n}=40)\end{array}$ & $\begin{array}{c}\text { Parakeet } \\
\text { auklet }^{c} \\
(\mathrm{n}=39)\end{array}$ \\
\hline $\begin{array}{l}\text { Peak current speed } \\
\text { Time of day }\end{array}$ & $\begin{array}{r}0.55 \cdots \\
-0.55 \cdots\end{array}$ & $\begin{array}{c}0.52 \cdots \\
-\end{array}$ & $0.54 \cdots$ \\
\hline \multicolumn{4}{|c|}{${ }^{\mathrm{A}} \mathrm{R}^{2}=0.43, p<0.0001 ;{ }^{\mathrm{b}} \mathrm{r}^{2}=0.27 ;{ }^{\mathrm{c}} \mathrm{r}^{2}=0.30$} \\
\hline
\end{tabular}

the 3 species (Bartlett's test, $\chi^{2}=3.85, \mathrm{df}=2, \mathrm{p}=0.15$ ). Modal locations differed significantly among the 3 species ( 1 -way ANOVA, $F_{2,33}=8.43, p=0.0011$ ). Multiple comparisons using the Tukey HSD procedure indicated that, during southward flow, the modal location of least auklets differed significantly from those of both crested auklets $(\mathrm{p}<0.011)$ and parakeet auklets ( $\mathrm{p}<$ 0.002 ), but that the modal distributions of crested and parakeet auklets did not differ significantly from each other $(p=0.88)$.

Peak current speed was a strong predictor of the abundance of each of the 3 auklet species along the transects (Fig. 10, Table 5). Time of day was a significant predictor of the abundance of least auklets, which decreased in abundance late in the day: crested and parakeet numbers were not significantly affected by time of day within the daylight hours in which we conducted our surveys (Table 5). In our analyses we have ignored time of day as a factor because the spatial patterns of habitat use were not sensitive to this variable.

Analyses of correlations between the numbers of each auklet species and the convergence rate in each 2 min bin within a transect, as measured with the ADCP, revealed species-specific responses to convergence and divergence processes within transects (Fig. 11). The mean correlations between numbers of least, crested, and parakeet auklets and convergence rate were $0.22( \pm 0.05 \mathrm{SE}, \mathrm{n}=43$ transects $),-0.20$ $( \pm 0.05 \mathrm{SE}, \mathrm{n}=39$ transects $)$, and $0.08( \pm 0.06 \mathrm{SE}, \mathrm{n}=43$ transects), respectively. Variances in the correlations were homogeneous among the 3 species, and the mean correlation differed significantly among species $\left(1\right.$-way ANOVA, $\left.F_{2,96}=14.68, \mathrm{p} \ll 0.0001\right)$. The $95 \%$ confidence interval (CI) constructed around the mean correlation for least auklets $(0.11,0.32)$ did not contain zero, indicating that, on average, least auklets tended to forage in areas of surface convergence. Similarly, the $95 \%$ CI constructed around the mean correlation

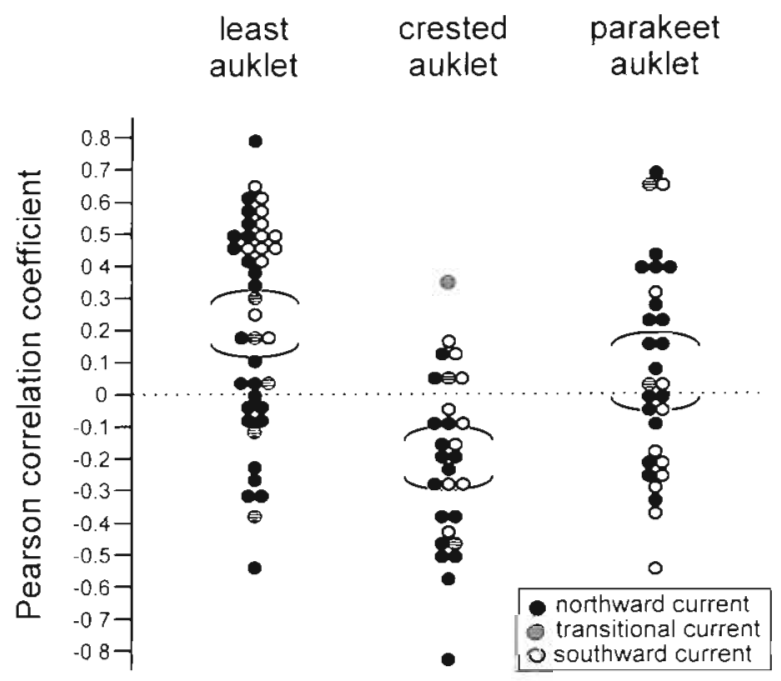

Fig. 11. Within-transect correlations between auklet numbers and the convergence rate in each bin for which ADCP data were available. Brackets indicate the $95 \%$ confidence intervals around the means

for crested auklets $(-0.30,-0.10)$ did not contain zero, indicating that crested auklets tended to forage in areas of surface divergence. However, the 95\% CI constructed around the mean correlation for parakeet auklets $(-0.04,0.20)$ contained zero, indicating that parakeet auklets did not show any tendency to occur consistently in either areas of convergence or divergence.

Within transects, both flow speed and direction influenced the separation of peaks of least and crested auklets. The distance between peak densities of least and crested auklets averaged $4.1 \mathrm{~km}( \pm 0.6 \mathrm{SE}, \mathrm{n}=20$ transects) when the current was flowing north, and averaged $1.8 \mathrm{~km}( \pm 0.3 \mathrm{SE}, \mathrm{n}=10$ transects) when the current was flowing south. The separation distance was significantly more variable during periods of northward flow (Bartlett's test, $\chi^{2}=9.7, \mathrm{df}=1, \mathrm{p}=$ 0.002 ), but increased as a function of current speed in both flow regimes (northward flow: $\mathrm{r}^{2}=0.26, \mathrm{n}=14$ transects with $\mathrm{ADCP}, \mathrm{p}=0.063$; southward flow: $\mathrm{r}^{2}=$ $0.61, n=8$ transects with ADCP, $p=0.023$ ).

The distance between peak densities of least and parakeet auklets averaged $2.8 \mathrm{~km}( \pm 0.4 \mathrm{SE}, \mathrm{n}=35$ transects) and did not vary with current direction ( $t=$ 1.21, $p=0.23$ ). However, the influence of current speed on separation distance did depend on current direction (ANCOVA: $F_{1,23}=4.42, p=0.047$ ), with a significant effect evident during periods of northward flow $\left(\mathrm{r}^{2}=\right.$ $0.43, n=17$ transects with ADCP, $p=0.004)$. No relationship was evident when flow was southward $\left(\mathrm{r}^{2}=\right.$ $0.04, n=10$ transects with ADCP, $p=0.59$ ).

The distance between peak densities of crested and parakeet auklets averaged $1.5 \mathrm{~km}( \pm 0.2 \mathrm{SE}, \mathrm{n}=27$ 
transects), and did not depend on either current direction (ANCOVA: $F_{1,18}=0.29, \mathrm{p}=0.60$ ) or peak current speed (ANCOVA: $F_{1,18}=0.61, p=0.44$ ).

Despite the small geographic area in which we sampled foraging auklets, the 3 species consumed strikingly different types of prey (Table 6). Each of the species tended to specialize on a prey assemblage: euphausiids and amphipods were the numerically dominant prey taken by 16 of 20 crested auklets; mol-

Table 6 . Foods used by 3 species of auklets over the Delarof sill in 1993. Values shown for each prey type are mean percentage contributions to the total number of identifiable prey items in food samples. One least and one parakeet auklet were excluded from the table because prey were too decomposed for specific identification

\begin{tabular}{|c|c|c|c|}
\hline $\begin{array}{l}\text { Prey taxon } \\
\text { Total no. of prey items sampled }\end{array}$ & $\begin{array}{l}\text { Least } \\
\text { auklet } \\
(n=27)\end{array}$ & $\begin{array}{l}\text { Crested } \\
\text { auklet }^{\mathrm{a}} \\
(\mathrm{n}=20)\end{array}$ & $\begin{array}{l}\text { Parakeet } \\
\text { auklet } \\
(n=10)\end{array}$ \\
\hline Unident gelatinous spp. & & & 29.16 \\
\hline $\begin{array}{l}\text { Heteropods } \\
\text { Clione spp. } \\
\text { Limacina spp. }\end{array}$ & $\overline{1.12}$ & $\overline{0}-$ & $\begin{array}{c}0.15 \\
16.23\end{array}$ \\
\hline $\begin{array}{l}\text { Cephalopods } \\
\text { Unident. squid } \\
\text { Unident. Macrura }\end{array}$ & $\begin{array}{l}0.03 \\
0.01\end{array}$ & $\begin{array}{c}11.88 \\
0.22\end{array}$ & $\begin{array}{c}10.80 \\
1.43\end{array}$ \\
\hline $\begin{array}{l}\text { Copepods } \\
\text { Eucalanus bungii } \\
\text { Neocalanus cnstatus } \\
\text { N. plumchrus/flemengeri } \\
\text { Unident. Calanoidae }\end{array}$ & $\begin{array}{r}0.38 \\
0.73 \\
91.41 \\
-\end{array}$ & $\begin{array}{c}0.12 \\
11.16 \\
7.74 \\
-\end{array}$ & $\begin{array}{c}- \\
10.23 \\
- \\
0.95\end{array}$ \\
\hline $\begin{array}{l}\text { Crabs } \\
\text { Atelecyclidae megalopa } \\
\text { Unident. crab megalopa } \\
\text { Unident. Paguridae }\end{array}$ & $\begin{array}{c}0.03 \\
- \\
-\end{array}$ & $\begin{array}{c}- \\
\overline{0} \\
0.02\end{array}$ & $\begin{array}{l}- \\
0.96 \\
0.15\end{array}$ \\
\hline $\begin{array}{l}\text { Amphipods } \\
\text { Hyperoche medusarum } \\
\text { Parathemisto japonica } \\
\text { P. pacifica } \\
\text { Primno spp. } \\
\text { Unident. Hyperiidae }\end{array}$ & $\begin{array}{l}- \\
3.16 \\
- \\
0.04\end{array}$ & $\begin{array}{l}- \\
1.02 \\
7.67 \\
0.04 \\
3.57\end{array}$ & $\begin{array}{l}- \\
- \\
- \\
- \\
7.74\end{array}$ \\
\hline $\begin{array}{l}\text { Euphausiids } \\
\text { Thysanoessa inermis (adults) } \\
\text { T. inspinata (adults) } \\
\text { T. spinifera (adults) } \\
\text { Thysanoessa spp. (adults) } \\
\text { Thysanoessa spp. (juveniles) }\end{array}$ & $\begin{array}{c}0.02 \\
<0.01 \\
- \\
- \\
2.98\end{array}$ & $\begin{array}{l}35.11 \\
- \\
5.86 \\
7.14 \\
5.70\end{array}$ & $\begin{array}{l}11.20 \\
- \\
- \\
- \\
-\end{array}$ \\
\hline $\begin{array}{l}\text { Shrimp } \\
\text { Unident. shrimp } \\
\text { Pandalidae zoea }\end{array}$ & $<0 . \overline{0}$ & $\begin{array}{c}2.16 \\
-\end{array}$ & $\begin{array}{l}0.15 \\
0.67\end{array}$ \\
\hline $\begin{array}{l}\text { Fish } \\
\text { Hexagrammus spp. } \\
\text { Sabastes spp. } \\
\text { Theragra chalcogramma } \\
\text { Zaprora silenis } \\
\text { Unident. Myctophidae } \\
\text { Unident. fish }\end{array}$ & $\begin{array}{l}- \\
- \\
- \\
- \\
-\end{array}$ & $\begin{array}{l}- \\
- \\
0.22 \\
0.21 \\
- \\
-\end{array}$ & $\begin{array}{l}0.83 \\
0.30 \\
4.63 \\
- \\
0.60 \\
3.80\end{array}$ \\
\hline 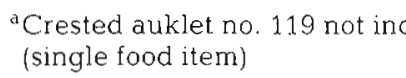 & ded i & nalys & \\
\hline
\end{tabular}

lusks and gelatinous items were dominant in 8 of 11 parakeet auklets; and copepods were dominant in 27 of 28 least auklets. The differences among species in the relative frequency of dominance of these prey classes was highly significant $\left(\chi^{2}=71,0\right.$, df $=4, p<$ 0.001 ). Over $90 \%$ of the prey items in the diets of least auklets consisted of the copepods $N$. plumchrus/flemengeri. In contrast, over $55 \%$ of the items in the diets of crested auklets were euphausiids, with copepods $(19 \%)$ and amphipods $(12 \%)$ being of lesser significance. Parakeet auklets took the most diverse diet, with no group of prey exceeding $30 \%$ of the items in the diet. Gelatinous zooplankton predominated (29\%), followed by mollusks (27\%), euphausiids $(11 \%)$ and copepods $(10 \%)$. Parakeet auklets also took more larval fish $(10 \%)$ than did the other species of auklets.

\section{DISCUSSION}

The coupling of physical and biological processes is an important aspect of the ecology of the ocean (Mann \& Lazier 1996). This coupling influences primary production (e.g. Pingree et al. 1975, Richardson 1985, Sambrotto et al. 1986, Whitledge et al. 1986) and the aggregation of zooplankton (e.g. Haury et al. 1978, Franks 1992, see 'Introduction'). Physical-biological coupling is also important for facilitating trophic transfer to fish (Uda 1973, Kiørboe et al. 1988) and other apex predators (e.g. Hoffman et al. 1981, Haney 1987, Vermeer et al. 1987, Brown \& Gaskin 1988, Wishner et al. 1988, Harrison et al. 1990, Schneider et al. 1990, Coyle et al. 1992). The role of tidal processes in trophic transfer is enhanced by spatial and temporal predictability, which permits predators to anticipate when and where prey will be available (Vermeer et al. 1987, Brown \& Gaskin 1988, Cairns \& Schneider 1990, Coyle et al. 1992, Becker et al. 1993, Irons 1998), a phenomenon well known to most coastal fishermen.

In this study, least, crested and parakeet auklets timed their foraging in a pass to correspond with the presence of strong tidal currents and exhibited a remarkable small-scale spatial segregation among the species. Similarly, the diets of these 3 auklet species differed in composition despite the proximity of the areas in which they foraged. Other studies have recorded differences in foraging distributions or in diets of auklets (reviewed by Hunt et al. 1993), but none have provided such dramatic evidence of consistent spatial and dietary segregation as is available in the present study. We conclude that least, crested and parakeet auklets exhibited strong preferences for particular prey types, and that these prey preferences resulted in small-scale differentiation of preferred foraging sites. The strong tidal currents provided the 
energy for the close juxtaposition of different mechanisms for enhancing prey availability.

Our results add to the growing body of evidence that in partitioning prey resources, seabirds utilize different marine habitats for foraging [(e.g. Ashmole \& Ashmole 1967, Pearson 1968, Cody 1973 (but see Bédard 1976), Croxall \& Prince 1980, Harrison et al. 1983, Croxall et al. 1984, Weimerskirch et al. 1985, 1986, 1988, Diamond \& Prys-Jones 1986)]. However, our conclusion that prey preferences determined choice of foraging habitat in this case contrasts with the view that seabirds are opportunistic, non-specialized foragers (Ainley 1980, Ainley et al. 1991, 1993b), and that choice of foraging habitat determines prey use (Diamond 1984, Adams \& Brown 1989, Ridoux \& Offredo 1989, Ainley et al. 1992, 1993a). For surface foragers, particularly in the tropics, prey may be sufficiently scarce in the near-surface layer that seabirds cannot afford to pass up opportunities to capture available prey. For subsurface foragers in some temperate and polar regions, and for some tropical open ocean foragers, the diversity of prey may be sufficiently restricted that all avian species must use similar prey within a given habitat. It is unclear whether the auklets present a special case, or whether individual seabirds or local populations will choose, when possible, to specialize on particular prey species as occurs in some gull populations (G. L. Hunt unpubl. data).

Our initial prediction that least, crested and parakeet auklets would be spatially segregated while foraging in the pass was correct, but our hypothesis for the proposed mechanism was falsified. Instead of the nearsurface-foraging least auklet using the upstream side of the sill, it was the deeper-diving crested auklet that consistently foraged upstream of the sill. Although we were not able to tow the MOCNESS sufficiently close to the bottom on the upstream side of the sill to sample zooplankton there during strong tidal flow, we hypothesize that epibenthic aggregations of euphausids were advected upward as the tidal current impinged on the sill. Crested auklets assembled above the upstream slope to forage in large numbers only when tidal currents were strong. In contrast, nearsurface-foraging least auklets were associated with surface convergences that formed on the downstream side of the sill. A striking result was the reversal of the order in which auklet species were arrayed relative to the sill when the tide changed. Similarly, Gaston \& Scofield (1995) noted that foraging seabirds changed the foraging area used with change in tidal currents in excess of $10 \mathrm{~km} \mathrm{~h}^{-1}$ near South Brother Island in Cook Strait, New Zealand, but they did not investigate the mechanisms involved.

Previous studies have shown that upwelling currents can result in the concentration of euphausiids at depth or in their transport to surface waters (Braune \& Gaskin 1982, Simard et al. 1986, Vermeer et al. 1987, Green et al. 1989, Coyle et al. 1992). In our study, epibenthic tidal currents were apparently sufficiently strong to advect the euphausiids upward into the foraging range of the crested auklets. The lack of euphausiids in the MOCNESS nets towed in near-surface waters and the lack of an acoustic signal attributable to euphausiid swarms suggests that the epibenthic aggregations were dispersed by the currents as the aggregations were advected upward, and that few euphausiids were carried to the surface. Thus, to forage on this prey, auklets had to be able to dive to the depth at which the epibenthic euphausid aggregations were still coherent.

Surface- and near-surface-foraging seabirds are known to feed in the vicinity of surface convergences (e.g. reviews by Hunt \& Schneider 1987, Hunt 1990), and least auklets in the northern Bering Sea make use of convergence fronts associated with the Alaska Coastal and Anadyr Currents (reviewed in Hunt et al. 1993, Hunt 1997). The convergence processes that we describe here are important for least auklets in the Aleutian Islands, particularly once the majority of the Neocalanus copepods have completed their ontogenetic migrations to depths of 500 to $1000 \mathrm{~m}$ (Miller \& Clemons 1988), where they become unavailable to foraging seabirds. The small patches of $N$. plumchrus/flemengeri remaining in the upper $5 \mathrm{~m}$ of the water column in July and August were apparently too scattered to be exploited profitably by least auklets. Thus, most auklets fed in the convergence areas where these plankters were concentrated.

The distance separating the peaks of foraging activity by the 3 species of auklets varied in response to changes in current speed and direction. The position of peak numbers of foraging parakeet auklets was apparently fixed near the top of the sill. The location of the peak number of crested auklets on a transect changed from one side of the sill to the other with tidal direction, but the distance between the peak of crested auklets and the peak of parakeet auklets on a transect was not sensitive to current speed or direction. We interpret this result as indicating that crested auklets were limited in their ability to reach euphausiids at depth, and that there was a limited range of current speeds sufficiently strong to upwell euphausiids into the foraging range of these auklets. Thus, crested auklets consistently dived for prey at about the same distance from the top of the sill regardless of the direction of the current. The foraging of least auklets was less topographically fixed than that of the crested auklets. Least auklets concentrated their foraging in the zones of convergence. These convergence zones not only changed sides of the sill with changes in the direction of the cur- 
rent, they also occurred at different distances from the sill as the areas of convergence moved through the tidal cycle. Thus, the separation of least auklets from foraging crested and parakeet auklets (on the flood tide) was sensitive to the speed of the current.

Measuring the density of near-surface zooplankton in the convergence zones proved difficult. Entrainment of • bubbles from surface turbulence meant that acoustic backscatter in these zones was a function of downwelling velocity (Farmer et al. 1995). Additionally, the intense physical turbulence in the convergence zones was also a potential source of acoustic backscatter (Stanton et al. 1994). Thus, the acoustic data from the convergence regions is probably best considered as indicative of downwelling rather than zooplankton biomass.

Data from the MOCNESS tows and acoustic sampling provided evidence that Neocalanus plumchrus/ flemengeri patches occurred predominately in the upper 5 to $7 \mathrm{~m}$. These near-surface-dwelling zooplankton were concentrated in the surface convergences when surface water was present, but there was no evidence for concentration of organisms in surface convergences when upwelled deeper water was at the surface. This result indicates that the surface convergences did not concentrate organisms that were not maintaining a near-surface position in the water column. Our measures of both the strength of the convergences and their ability to concentrate nearsurface-dweiling zooplankton were likely to be underestimates. It was difficult to obtain quantitative samples in the upper $5 \mathrm{~m}$ of the water column which was disturbed by the ship's wake, and the net hauls covered an area considerably larger than the convergence zones, thus diluting the zooplankton signal. We are persuaded by the net samples with high concentrations of $N$. plumchrus/flemengeri, and by the high numbers of foraging least auklets with copepods in their stomachs, that the convergence zones were indeed areas in which these copepods were aggregated.

Two mechanisms were responsible for the convergences: surfacing internal waves and quasi-permanent convergent tidal fronts. Evidence for the existence of the internal waves included the surface boils, alternating areas of convergence and divergence which corresponded to alternating zones of warmer and cooler surface water, and the undulating bottom of the upper mixed layer as seen on the ship's fathometer. These relatively small features were usually also evident in the $A D C P$ records, which were sometimes too coarse to resolve the smallest events. There was no doubt about the location of the primary tidal convergence front that separated the convergence zone from the relatively quiet water downstream of the sill. This front was marked by strong flow gradients in the ADCP, marked changes in surface temperature, and the accumulation of flotsam.
In the Delarof region, the features of the convergence zone between the sill and the tidal front were similar to those described by Farmer et al. (1995) for Haro Strait. In their study, boils consisted of $175 \mathrm{~m}$ wide patches of smooth, upwelled water surrounded by $15 \mathrm{~m}$ wide rings of rough water indicating regions of intense downwelling. In the Delarof region, the internal waves appeared as temperature and salinity spikes in the TS traces from the MOCNESS tows, and as dark streaks in the echograms. The distance between temperature peaks varied between 50 and $150 \mathrm{~m}$, with the zones of the most intense downwelling, as judged from traces on the echograms, being on the order of $15 \mathrm{~m}$, similar to the width of the downwelling areas described by Farmer et al. (1995).

The simple vertical displacement of surface concentrations of zooplankton to greater depths was unlikely to have enhanced the foraging opportunities of the auklets. Most likely, the enhancement mechanism(s) involved small-scale processes within the shear zone that divided the upwelling and downwelling water masses within the convergence (Franks 1992). If this supposition is correct, then the auklets may have been responding to individual patches of zooplankton on the order of 10 to $20 \mathrm{~m}$ in width.

Our observations demonstrate that physical-biological coupling is important in controlling trophic transfer to apex predator populations and that transfer may be concentrated in a small proportion of their foraging ranges where there are unusually favorable foraging conditions. When concentrated, high-trophic-level organisms are extremely vulnerable to over-exploitation (in the case of those that are exploited) or to contamination by pollutants such as oil that may also become concentrated in the preferred foraging areas. Thus, understanding the mechanisms that result in the concentration of apex predators and predicting where predators may concentrate will have important implications for the conservation of these species.

Acknowledgements. We thank the Captain and the crew of the RV 'Alpha Helix' for their support and help with the field program. We thank M. B. Decker, S. Gay, C. Griffith, A. S. Kitaysky, M. Miller, K. Mills, K. Stone, M. Vallarino, E. Woehler and $J$ Zamon for help with data collection and $G$. Updegraf and $M$. Vallarino for help with programming. P. Hunt, F. Mehlum and 3 anonymous reviewers provided helpful comments on an earlier version of the manuscript. The research was supported in part by National Science Foundation grants DPP-912283 and DPP-9321636.

\section{LITERATURE CITED}

Adams NJ, Brown CR (1989) Dietary differentiation and trophic relationships in the sub-Antarctic penguin community at Marion Island. Mar Ecol Prog Ser 57:249-258 
Ainley DG (1980) Birds as marine organusms: a review. Calif Coop Ocean Fish Invest Rep 21:48-53

Ainley DG, Fraser WR, Smith WO, Hopkins TL, Torres JJ (1991) The structure of upper level pelagic food webs in the Antarctic: effect of phytoplankton distribution. J Mar Syst 2:111-122

Ainley DG, Ribic CA, Fraser WR (1992) Does prey preference affect habitat choice in Antarctic seabirds? Mar Ecol Prog Ser 90:207-221

Ainley DG, Ribic CA, Spear LB (1993a) Species-habitat relationships among Antarctic seabirds: a function of physical or bjological factors? Condor 95:806-816

Ainley DG, Sydeman WJ, Parrish RH, Lenarz WH (1993b) Oceanic factors influencing occurrence patterns of young rockfish (Sebastes) in central California: a predator's perspective. Calif Coop Ocean Fish Invest Rep 34:133-139

Ashmole NP, Ashmole MJ (1967) Comparative feeding ecology of seabirds of a tropical oceanic island. Bull Peabody Mus Nat Hist 24:1-131

Barroclough WE, LeBrasseur RJ, Kennedy OD (1969) Shallow scattering layer in the subarctic Pacific Ocean: detection by high frequency echosounder. Science 166:61.1.-61.3

Becker PH, Frank D, Sidmann SR (1993) Temporal and spatial pattern of Common Tern's Sterna hirundo foraging in the Wadden Sea. Oecologia 93:389-393

Bédard J (1969) Feeding of the least, crested, and parakeet auklets around St. Lawrence Island, Alaska. Can J Zool 47:1025-1050

Bédard J (1976) Coexistence, coevolution and convergent evolution in seabird communities: a comment. Ecology $57: 177-184$

Braune BM, Gaskin DE (1982) Feeding ecology of nonbreeding populations of larids off Deer Island, New Brunswick Auk 99:67-76

Briggs KT, Ainley DG, Spear LB, Adams PB, Smith SF (1988) Feeding of two alcids at central California upwellings. Proc Int Ornith Congr 19:987-990

Brown RGB, Gaskin DE (1988) The pelagic ecology of the grey and red- necked phalaropes Phalaropus fulicarius and $P$. lobatus in the Bay of Fundy, eastern Canada. Ibis $130: 234-250$

Burger A.E (1991) Maximum diving depths and underwater foraging in alcids and penguins. In: Montevecchi WA, Gaston AJ (eds) Studies of high-latitude seabirds. 1 Behavioural, energetic, and oceanographic aspects of seabird foraging ecology. Can Wildl Serv Occas Pap 68, Ottawa, p 9-15

Burger AE, Powell DW (1990) Diving depths and diet of Cassin's auklet at Reef Island, British Columbia. Can J Zool 68:1572-1577

Cairns DL, Schneider DC (1990) Hotspots in cold water: feeding habitat selection by thick-billed murres. Stud Avian Biol 14:52-60

Cody ML (1973) Coexistence, coevolution and convergent evolution in seabird communities. Ecology 54:31-44

Cooney RT (1989) Acoustic evidence for the vertical partitioning of biomass in the epipelagic zone of the Gulf of Alaska. Deep Sea Res 36:1177-1189

Coyle KO, Hunt GL Jr, Decker MB, Weingartner TJ (1992) Murre foraging, epibenthic sound scattering and tidal advection over a shoal near St. George Island, Bering Sea. Mar Ecol Prog Ser 83:1-14

Croxall JP, Prince PA (1980) Food, feeding ecology and ecological segregation of seabirds at South Georgia. Biol J Linn Soc 14:103-131

Croxall JP, Ricketts C, Prince PA (1984) Impact of seabirds on marine resources, especially krill, of South Georgia waters. In: Whittow GC, Rahn H (eds) Seabird energetics. Plenum Press, New York, p 285-317

Day RH, Byrd GV (1989) Food habits of the whiskered auklet at Buldir Island, Alaska. Condor 91:65-72

Decker MB, Hunt GL Jr (1996) Foraging by murres (Uria spp.) at the tidal front surrounding the Pribilof Islands, Alaska. Mar Ecol Prog Ser 139:1-10

Diamond AW (1984) Feeding overlap in some tropical and temperate seabird communities. Stud Avian Biol 8:24-46

Diamond AW, Prys-Jones RP (1986) The biology of terns nesting at Aldabra Atoll, Indian Ocedn, with particular reference to breeding seasonality. J Zool (Lond) 210:527-549

Farmer DM, D'Asaro EA, Trevorrow MV, Dairiki GT (1995) Three-dimensional structure in a tidal convergence front. Cont Shelf Res 15:1649-1673

Fragopoulu N, Lykakis J $\rfloor$ (1990) Vertical distribution and nocturnal migration of zooplankton in relation to the development of the seasonal thermocline in Patraikos Gulf. Mar Biol 104:381-387

Franks PJS (1992) Sink or swim: accumulation of biomass at fronts. Mar Ecol Prog Ser 82:1-12

Franks PJS (1997) New models for the exploration of biological processes at fronts. ICES J Mar Sci 54:161-167

Gagnon M, Lacroix G (1982) The effects of tidal advection and mixing on statistical dispersion of zooplankton. J Exp Mar Biol Ecol 56:9-22

Gaston AJ, Scofield P (1995) Birds and tuataras on North Brother Island, Cook Strait, New Zealand. Notornis 42 : $27-41$.

Genin A, Haury L, Greenblatt P (1988) Interaction of migrating zooplankton with shallow topography: predation by rockfishes and intensification of patchiness. Deep Sea Res 35:151-175

Green CH, Wiebe PH, Burczynski J (1989) Analyzing zooplankton size distribution using high-frequency sound. Limnol Oceanogr 34:163-178

Haney JC (1987) Ocean internal waves as sources of smallscale patchiness in seabird distribution on the Blake Plateau. Auk 104:129-133

Haney JC, McGillivary PA (1985a) Aggregations of Cory's shearwaters (Calonectris diomedea) at Gulf Stream fronts. Wilson Bull 97:191-200

Haney JC, McGillivary PA (1985b) Midshelf fronts in the South Atlantic Bight and their influence on seabird distribution and seasonal abundance. Biol Oceanogr 3:401-430

Harrison CS, Hida TS, Seki. MP (1983) Hawajian seabird feeding ecology. Wildl Monogr 47:1-70

Harrison NM (1984) Predation on jellyfish and their associates by seabirds. Limnol Oceanogr 29:1335-1337

Harrison NM (1987) Foraging behavior and coexistence of seabirds in the Bering Sea. PhD thesis, University of California, Irvine

Harrison NM. Hunt GL Jr, Cooney RT (1990) Front affecting the distribution of seabirds in the northern Bering Sea Polar Res 8:29-31

Haury LR, McGowan JA, Wiebe PH. (1978) Patterns and processes in the time-space scales of plankton distributions. In: Steele JH (ed) Spatial pattern in plankton communities Plenum Press, New York, p 277-227

Haury LR, Pieper RE (1987) Zooplankton: scales of biological and physical events. In: Soule DF, Kleppel GS (eds) Marine organisms as indicators. Springer-Verlag, New York, p 35-72

Haury LR, Wiebe PH (1982) Fine-scale multi-species aggregations of oceanic zooplankton. Deep Sea Res 29:915-921

Herman AW, Sambrotto DD, Longhurst AR (1981) Vertical and horizontal distribution patterns of copepods near the 
shelf break south of Nova Scotia. Can $J$ Fish Aquat Sci 38:1065-1076

Hoffman W, Heinemann D, Wiens JA (1981) The ecology of seabird feeding flocks in Alaska. Auk 98:437-456

Hunt GL Jr (1990) The distribution of seabirds at sea: physical and biological aspects of their marine environment. Current Topics in Avian Biology. Proc Int Centennial Meeting Deutsche Ornithologen Gesellschaft, Bonn, p 167-171

Hunt GL Jr (1997) Physics, zooplankton, and the distribution of least auklets in the Bering Sea-a review. ICES J Mar Sci (in press)

Hunt GL Jr, Burgeson B, Sanger GA (1981) Feeding ecology of seabirds of the eastern Bering Sea. In: Hood DW, Calder JA (eds) The eastern Bering Sea shelf: oceanography and resources. National Oceanic and Atmospheric Administration, Washington, DC, p 629-647

Hunt GL Jr, Coyle KO, Hoffman S, Decker MB, Flint EN (1996) Foraging ecology of short-tailed shearwaters near the Pribilof Islands, Bering Sea. Mar Ecol Prog Ser 141: $1-11$

Hunt GL Jr, Harrison NM (1990) Foraging habitat and prey taken by least auklets at King Island, Alaska. Mar Ecol Prog Ser 65:141-150

Hunt GL Jr, Harrison NM, Piatt JF (1993) Foraging ecology as related to the distribution of planktivorous auklets in the Bering Sea. In: Vermeer K, Briggs KT, Morgan KH, SiegelCausey $\mathrm{D}$ (eds) The status, ecology, and conservation of marine birds of the North Pacific. Can Wild Ser Spec Publ, Ottawa, p 18-26

Hunt GL Jr, Schneider DC (1987) Scale-dependent processes in the physical and biological environment of marine birds. In: Croxall JC (ed) Seabirds: feeding biology and role in marine ecosystems. Cambridge University Press, Cambridge, p 7-41

Irons D (1998) Foraging area fidolity of individuô seảbin ús in relation to tidal cycles and flock feeding. Ecology 79 : $647-655$

Kinder TH, Hunt GL Jr, Schneider D, Schumacher JD (1983) Correlation between seabirds and oceanic fronts around the Pribilof Islands, Alaska. Estuar Coast Shelf Sci 16:309-319

Kiørboe T, Munk P, Richardson K, Christiansen V, Paulsen $\mathrm{H}$ (1988) Plankton dynamics and herring larval growth, drift and survival in a frontal area. Mar Ecol Prog Ser 44: $205-219$

Mann KH, Lazier JRN (1996) Dynamics of marine ecosystems, 2nd edn. Blackwell, Boston

Miller CB, Clemons MJ (1988) Revised life history analysis for large grazing copepods in the subarctic Pacific Ocean. Prog Oceanogr 20:293-313

Obst BS, Russell RW, Hunt GL Jr, Eppley ZA, Harrison NM (1995) Foraging radii and energetics of least auklets (Aethia pusilla) breeding on three Bering Sea islands. Physiol Zool 68:647-672

Parsons TR, Maita Y, Lalli CM (1984) A manual of chemical and biological methods for seawater analysis. Pergamon Press, Oxford

Pearson TH (1968) The feeding biology of sea-bird species breeding on the Farne Islands. J Anim Ecol 37:521-552

Piatt JF, Pinchuk A, Kitaysky A (1992) Auklets, eddies and plankton in Bering Strait. In: Piatt JF, Pinchuk A, Kitaysky A, Springer AM, Hatch SA (eds) Foraging distribution and feeding ecology of seabirds at the Diomede Islands, Bering Strait. US Fish and Wildlife Service Final Report for Minerals Management Service (OSC Study MMS 920041), Anchorage, AK, p 1-76

Pingree RD, Forster GR, Morrison GK (1974) Turbulent convergent tidal fronts. J Mar Biol Assoc UK 54:469-479
Pingree R, Pugh P, Holligan PM. Forster G (1975) Summer phytoplankton bloom and red tides in the approaches to the English Channel. Nature 258:672-677

Richardson K (1985) Plankton distribution and activity in the North Sea/Skagerrak-Kattegat frontal area in April 1984. Mar Ecol Prog Ser 26:233-244

Ridoux V, Offredo C (1989) The diets of five summer breeding seabirds in Adélie Land. Antarctica. Polar Biol 9:137-145

Sambroto RN, Niebauer HJ, Georing JJ, Iverson RL (1986) Relationships among vertical mixing, nitrate uptake and phytoplankton growth during the spring bloom in the southeast Bering Sea middle shelf. Cont Shelf Res 5 $161-198$

Schneider DC, Harrison NM, Hunt GL Jr (1990) Seabird diet at a front near the Pribilof Islands, Alaska. Stud Avian Biol 14:61-66

Simard Y, de Ladurantaye R, Therriault JC (1986) Aggregation of euphausiids along a coastal shelf upwelling environment. Mar Ecol Prog Ser 32:203-215

Sowls AL, Hatch SA, Lensink CJ (1978) Catalog of Alaskan seabird colonies. US Fish and Wildlife Service FWS OBS-78/78, Washington, DC

Springer AM, Roseneau DG (1985) Copepod-based food webs: auklets and oceanography in the Bering Sea. Mar Ecol Prog Ser 21:229-237

Stanton TK, Wiebe PH, Chu D, Goodman L (1994) Acoustic characterization and discrimination of marine zooplankton and turbulence. ICES J Mar Sci 51:469-479

Thompson RE, Golding TJ (1981) Tidally induced upwelling by the Great Barrier Reef. J Geophys Res 86:6517-6521

Thompson RE, Wolanski $E$ (1984) Tidal period upwelling within Raine Island Entrance, Great Barrier Reef. J Mar Res 42:787-808

Uda $M$ (1973) Pulsative fluctuations of oceanic fronts in association with tuna fishing grounds and fisheries. $J$ Fac Mar Sci Technol Tokai Univ 7:245-265

Vermeer KI, Fulton JO, Sealy SG (1985) Differential use of zooplankton prey by ancient murrelets and Cassin's auklets in the Queen Charlotte Islands. J Plankton Res 7:443-459

Vermeer K, Szabo I, Greisman P (1987) The relationship between plankton-feeding Bonaparte's and mew gulls and tidal upwelling at Active Pass, British Columbia. J Plankton Res 9:483-501

Weimerskirch H, Bartle JA, Jouventin P, Stahl JC (1988) Foraging ranges and partitioning of feeding zones in three species of southern albatrosses. Condor 90:214-219

Weimerskirch $H$, Jouventin P, Mougin JL, Stahl JC, Van Beveren M (1985) Banding recoveries and the dispersal of seabirds breeding in French Austral and Antarctic territories. Emu 85:22-23

Weimerskirch $H_{1}$, Jouventin P, Stahl JC (1986) Comparative ecology of the six albatross species breeding on the Crozet Islands. Ibis 128:195-213

Whitledge TE, Reeburgh WS, Walsh JJ (1986) Seasonal morganic nitrogen distributions and dynamics in the southeastern Bering Sea. Cont Shelf Res 5:109-132

Wishner K, Durbin E, Durbin A, Macauley M, Winn H, Kenney $R$ (1988) Copepod patches and right whales in the Great South Channel off New England. Bull Mar Sci 43: $825-844$

Wolanski EE, Drew E, Abel KM, O'Brian J (1988) Tidal jets, nutrient upwelling and their influence on the productivity of the alga Halimeeda in the ribbon reefs, Great Barrier Reef. Estuar Coast Shelf Sci 26:169-201

Wolanski E, Hamner WH (1988) Topographically controlled fronts in the ocean and their biological influence. Science $241: 177-181$

Submitted: October 15, 1997; Accepted: March 11, 1998

Proofs received from author(s): May 27, 1998 